Universidade de São Paulo

Instituto de Psicologia

Thiago Camargo Corrêa

Estudo do Comportamento Cooperativo Por Meio do Dilema do Prisioneiro

Study of Cooperative Behavior Through the Prisoner's Dilemma

São Paulo

2020 
Thiago Camargo Corrêa

\section{Estudo do Comportamento Cooperativo Por Meio do Dilema do Prisioneiro}

Dissertação apresentada ao Instituto de Psicologia da Universidade de São Paulo para obtenção do título de Mestre em Ciências.

Área de concentração: Neurociências e Comportamento

Orientadora: Prof. ${ }^{\mathrm{a}}$ Dr. ${ }^{\mathrm{a}}$ Ivana Brito

Co-orientador: Prof. Dr. Hamilton Haddad Jr.

São Paulo 
Autorizo a reprodução e divulgação total ou parcial desse trabalho, por qualquer meio convencional ou eletrônico para fins de estudo e pesquisa, desde que citada a fonte

Catalogação na publicação

Biblioteca Dante Moreira Leite

Camargo Corrêa, Thiago

Estudo do Comportamento Cooperativo Por Meio do Dilema do Prisioneiro / Thiago Camargo Corrêa; orientadora Ivana Brito. São Paulo, 2016.

$60 \mathrm{f}$.

Dissertação (Mestrado - Programa de Pós-Graduação em Psicologia. Área de Concentração: Neurociências e Comportamento) - Instituto de Psicologia da Universidade de São Paulo.

1. Ocitocina 2. Tomada de decisão 3. Cooperação 4. Teoria dos jogos I. Brito, Ivana, orient. II. Título.

Instituto de Psicologia da Universidade de São Paulo 
Nome: Thiago Camargo Corrêa

Título: Estudo do Comportamento Cooperativo Por Meio do Dilema do Prisioneiro

Dissertação apresentada ao Instituto de Psicologia da Universidade de São Paulo para obtenção do título de Mestre em Ciências.

Área de concentração: Neurociências e Comportamento

Orientadora: Prof. ${ }^{a}$ Dr. ${ }^{a}$ Ivana Brito

Aprovado em:

Banca Examinadora

Prof.(a) Dr.(a):

Instituição:

Julgamento:

Assinatura:

Prof.(a) Dr.(a):

Instituição:

Julgamento:

Assinatura:

Prof.(a) Dr.(a):

Instituição:

Julgamento:

Assinatura: 


\section{Dedicatória}

Dedico o presente trabalho ao meus pais, que são meu maior apoio nos momentos de angustia e que fizeram de tudo para tornar esse sonho possível. 


\section{Agradecimentos}

Aos meus dois orientadores Prof. Dr. Hamilton Haddad Jr e a Prof. ${ }^{a}$ Dr. ${ }^{a}$ Ivana Brito. A contribuição de vocês foi além da intelectual requerida para a conclusão desse trabalho.

O aprendizado que eu obtive com a convivência de vocês transpõem o acadêmico e se consolida em várias lições nos aspectos sociais. Obrigado!

Aos meus amigos do Laboratório: Charles, Jimmy, Pedro, Leila, Jéssica e Raphaela, que me proporcionaram um ambiente agradável cheio de companheirismo e permissivo a discussões de alto nível, tanto acadêmicas quanto de diversos outros assuntos se reflete nesse texto. Obrigado!

Aos professores Marcos Vinicius Chrysóstomo Baldo e Esteban Fernandez Tuesta pelo auxilio na elaboração da metodologia e da analise de dados. Obrigado!

A Cristiane, pois seu apoio pessoal, emocional e intelectual fez parte desse trabalho e sem você chegar a esse final não seria possível. Obrigado!

A CAPES agradeço o apoio financeiro imprescindível para a execução deste trabalho. $O$ investimento em ciência e tecnologia é a porta para um futuro melhor. Obrigado! 
"Winner winner, chicken dinner!"

Robert Luketic, 21 (Quebrando a Banca) - 2008 


\section{Resumo}

$\mathrm{Na}$ vida cotidiana, as situações de tomada de decisão são altamente complexas e desestruturadas, principalmente quando estão relacionadas à interações sociais. Para tanto, integrar informações sobre os estados mentais do outro nos permite fazer previsões sobre seu comportamento, direcionando nossos comportamentos. Nesse cenário, muitos organismos desenvolvem estratégias comportamentais cooperativas, o que tem se apresentado como um desafio para a teoria evolutiva. Partindo do pressuposto que as bases das interações sociais apresentam probabilidades, é possível desenvolver modelos que demonstrem a cooperação como uma estratégia evolutivamente estável. Estudos vêm se utilizando de paradigmas da teoria dos jogos para simular nossas escolhas do cotidiano. Uma dessas ferramentas é o famoso jogo dilema do prisioneiro iterado, onde pessoas devem tomar decisões sucessivas sobre cooperar ou não cooperar, buscando otimizar seus ganhos.

Ainda, o envolvimento da ocitocina com vários elementos da cognição social, como a promoção de comportamentos pró-sociais, também vem sendo demonstrado em estudos com jogos de cooperação, sugerindo que a ocitocina afete a aceitação de riscos sociais decorrentes de interações interpessoais. Assim, nosso trabalho investigou a influência da ocitocina sobre a confiança adquirida entre jogadores no processo de tomada de decisão, frente a um jogo sequencial inspirado no dilema do prisioneiro iterado. O estudo foi realizado com 80 estudantes universitários do sexo masculino, saudáveis, com idades variando entre 19 a 45 anos. Os participantes, divididos entre os grupos ocitocina e placebo, foram convidados a jogar o dilema do prisioneiro iterado para dois jogadores, podendo interagir num intervalo que variava de no mínimo 10 e no máximo 30 vezes, dependendo das escolhas ao longo do jogo. Em linhas gerais, nossos resultados demonstraram que o grupo ocitocina apresentou um número maior de cooperações totais e cooperações mútuas, com estabilização do comportamento de cooperação na segunda metade do jogo. Posto isto, e, juntamente com trabalhos que examinam as bases neurais do comportamento cooperativo, acreditamos que a ocitocina possa modular a cooperação entre indivíduos. 


\begin{abstract}
In everyday life, decision-making situations are highly complex and unstructured, especially when they are related to social interactions. Therefore, integrating information about the other's mental states allows us to make changes in their behavior, directing our uses. In this scenario, many organisms develop cooperative behavioral strategies, or which present a challenge to evolutionary theory. Assuming that the foundations of active interactions are probable social interactions, it is possible to develop models that demonstrate cooperation as an evolutionarily stable strategy. Studies have been using game theory paradigms to simulate our everyday choices. One tool is the famous itereted prisoner's dilemma, where people must make successive decisions about cooperation or not, seeking to optimize their gain.

Also, the involvement of oxytocin with various elements of social cognition, such as the promotion of professional use, has also been demonstrated in studies with cooperative games, suggesting that oxytocin has an interactive social risk performance. Thus, our work investigated the influence of oxytocin on the confidence gained among players in the decision-making process, facing a sequential game inspired by the iterated prisoner's dilemma. The study was conducted with 80 male college students, aged 19 to 45 years. Participants, split between the oxytocin and placebo groups, were invited to play the two-player iterated prisoner's dilemma, with a range of at least 10 and up to 30 teams following the options throughout the game. Overall, our demonstrated results for the oxytocin group show a larger number of full cooperations and mutual cooperatives, with the establishment of cooperative behavior in the second half of the game. That said, and together with the papers that examine neural foundations of cooperative behavior, we believe that oxytocin can modulate cooperation between individuals.
\end{abstract}




\section{Lista de Figuras}

Figura 1. Opções fornecida a cada um dos prisioneiros e resultados para combinações das possíveis tomada de decisão.

Figura 2. Representação das possíveis rotas e destinos da ocitocina inalatória.

Figura 3. Tabela de ganhos ou perdas para o jogo dilema do prisioneiro iterado proposto.

Figura 4. Interface do PsychoPy.

Figura 5. Disposição do setup experimental.

Figura 6. Telas apresentadas aos jogadores a cada tomada de decisão.

Figura 7. Total de cooperações realizadas pelos jogadores do grupo placebo e ocitocina, ao longo de todos os jogos.

Figura 8. Porcentagem de cooperações a cada rodada para o grupo placebo e ocitocina.

Figura 9. Porcentagem de cooperações.

Figura 10. Soma acumulada de pontos por grupo ao longo das rodadas.

Figura 11. Diferença entre as médias das pontuações em rodadas subsequentes.

Figura 12. Soma acumulada de pontos em simulação de estratégias para o jogo dilema do prisioneiro iterado em 30 rodadas. 


\section{Lista de Tabelas}

Tabela 1. Comparação das situações inicial e final do teste de POMS. 


\section{Sumário}

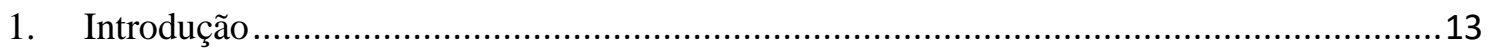

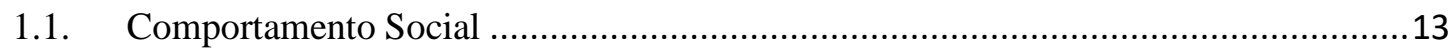

1.2. Teoria dos jogos e comportamento humano............................................................15

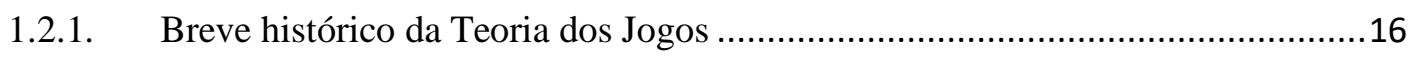

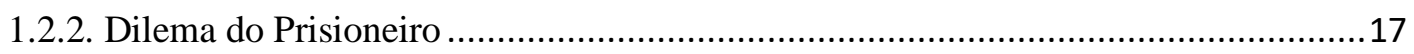

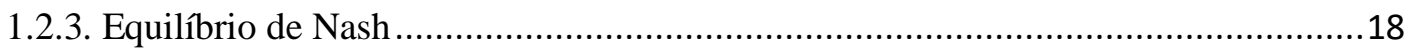

1.2.4. Jogos finitos e infinitos ................................................................................. 19

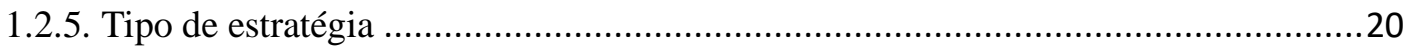

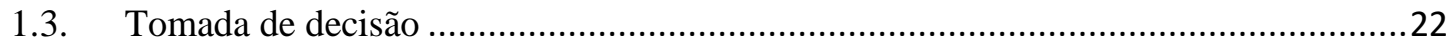

1.4. Ocitocina e comportamentos pró-sociais ………...................................................23

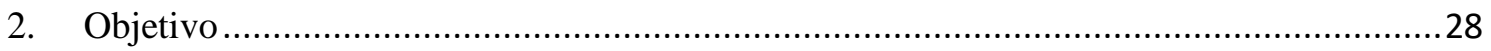

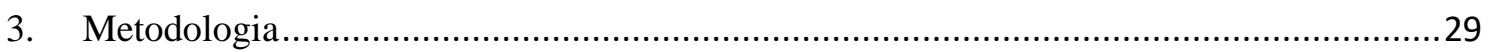

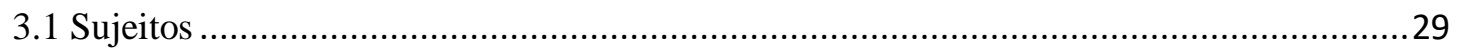

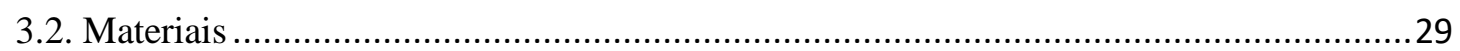

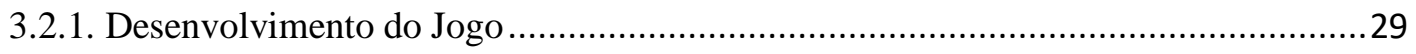

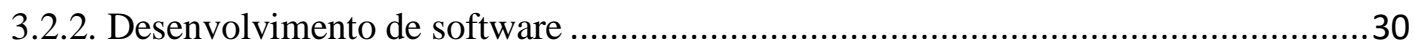

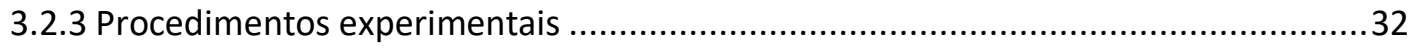

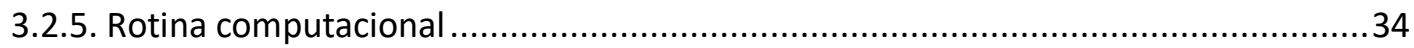

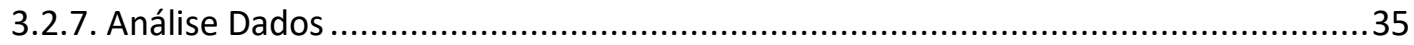

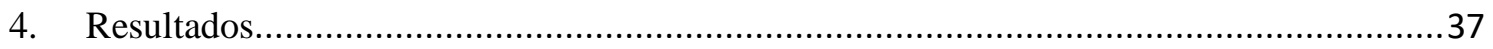

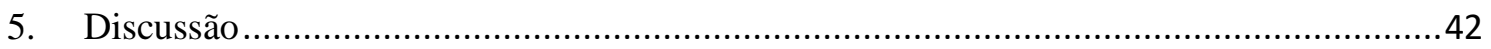

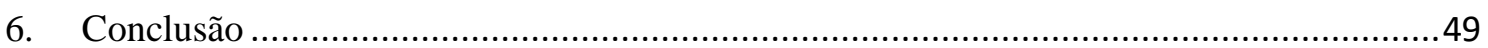

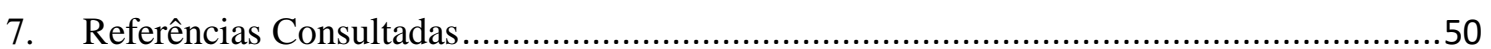

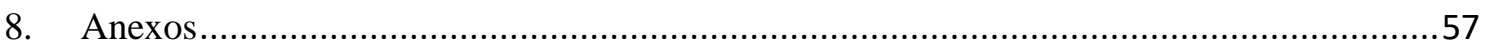




\section{Introdução}

\subsection{Comportamento Social}

A teoria do cérebro social vem sendo extensamente construida nas últimas décadas (Gazzaniga, 1985; Adolphs et al., 1994; Damazio, 1995; Heatherton et al., 2004; Quervain et al., 2004), tendo como principal contribuição e desafio, a integração de diferentes áreas do saber. Assim, a abordagem do comportamento social pode se dar pela psicologia social, enfatizando a singularidade do comportamento humano e do indivíduo, bem como o seu ambiente e entorno social. Por outro lado, a sociobiologia e psicologia evolutiva estudam o comportamento social como um tópico da etologia, contínuo aos estudos de comportamentos motivados em diferentes animais.

Embora a presença dessas duas ênfases separe alguns aspectos do comportamento social, elas podem converger, ao invés de conflitar, permitindo uma reconciliação entre as abordagens psicológicas e biológicas uma vez que, a regulação neural do comportamento social reflete tanto o controle inato ao mecanismos cognitivos, como aspectos adquiridos, contextuais e volitivos (Rose \& Rache, 2013). Neste cenário, importantes contribuições foram dadas por Konrad Zacharias Lorens (1903-1989), por suas ideias sobre epistemologia evolucionista, na tentativa de integrar diferentes campos do saber (Garcia, 2005), embora tenha sido reconhecido, principalmente, por sua contribuição para o estabelecimento da etologia (Gracia \& Otta 2002).

Grande corpo do conhecimento científico envolvendo as bases neurais de comportamento social desenvolveu-se por meio de estudos com humanos, modelos animais e modelos matemáticos, muitas vezes associados aos estudos sobre alterações e disturbios de comportamento, causados por lesões e patologias do sistema nervoso central, e também pela influência de fármacos neuromodeladores sobre o comportamento (Cacioppo 1994; Adolphs et al. 1998; Dalley et al. 2004; Barraclough, 2004; Lee, 2008).

Os comportamentos sociais podem envolver qualquer interação intra ou interespecífica e incluem comunicação, agressão, comportamento de acasalamento e comportamento parental, tornando o outro ser como perceptivo, pensante, moral e intencional (Gammie, 2010; Rilling \& Sanfey, 2011). Dessa forma, as interações entre 
indivíduos são atos, ações ou práticas mutualmente orientadas. Mesmo na ausência do contato ou aproximação física, como uma conversa ao telefone ou envios de mensagens por dispositivos eletrônicos existe a interação social. Assim, a interação social não é estabelecida por contato físico, comportamento específico ou distância controlada, mas sim pela orientação ao outro sujeito (Gammie, 2010; Rilling \& Sanfey, 2011).

Muitos de nossos comportamentos são conduzidos por um sistema de reforço (uma consequência que aumenta a probabilidade de ocorrência de resposta) ou de punição (uma consequência que diminui a probabilidade de ocorrência de resposta) e, assim como qualquer outro animal, buscamos uma variedade de recompensas (Souza, 2001; Rilling, et al., 2008; Rilling \& Sanfey, 2011; Chang \& Pham, 2013; Janak \& Tye, 2015; Salamone et al., 2018) alterando a relação entre comportamento e consequências manifestadas (Souza, 2001). Um exemplo é a atividade de forragear dos animais que despende um gasto energético elevado e, como alguns recursos não estão em abundância no meio, os animais são expostos a uma tomada de decisão entre sair para outro local, gastando parte de sua energia em busca de alimento/recompensa (incerteza de ganho), ou permanecer no mesmo local economizando suas energias, mas com reservas escassas de alimento (ganho mínimo) (Charnov, 1976; Chang \& Pham, 2013).

Podemos ver semelhanças entre o comportamento de forrageamento e algumas das decisões diárias que tomamos, sendo que a informação social tem o valor de recompensa (Chang \& Pham, 2013). Como os recursos (i.e., informações sociais) são geralmente distribuídos de forma dispersa, modelos experimentais se mostram bastante interessantes para observar as tomadas de decisões em situações controladas, uma vez que a busca de informações pode acarretar em reforço ou punições. Esses tipos de experimentos foram bastante explorados pelo psicólogo Burrhus Frederic Skinner durante o século XX (1904-1990), apresentando aspectos do estudo sobre comportamento que nos influenciam até hoje (Sampaio, 2005). Esses tipos de situações são bastante análogos a um jogo, onde devemos escolher entre diversas opções julgando qual nos trará um maior benefício ou um menor prejuízo (Hart, 1992). As decisões que tomamos podem refletir em outras pessoas (i.e. competidores ou cooperadores) que também buscam maximizar seus ganhos próprios, de forma que sempre que um conjunto de indivíduos estiver envolvido em tomada de decisões e elas os afetarem mutuamente, podemos dizer que o grupo está em situação de jogo (Axelrod, 1984; Osborne, 2000; Sanfey et al., 2003; Sejwal, 2014). Assim, podemos utilizar a estrutura 
dos jogos matemáticos para simular o comportamento expressado, motivando os participantes a tomarem decisões por recompensas (Lee, 2008), visto que as interações sociais se apresentam de formas cooperativas e reforçadoras (Rilling et al., 2002; Rand, et al., 2012), ou punitivas (Quervain, et al., 2004).

Podemos entender cooperação como um comportamento individual que apresenta custos para se engajar em atividades conjuntas e que confere benefícios excedentes aos custos para outros membros do grupo, ou seja, reduzir ganhos individuais máximos em troca de um ganho coletivo. Esse conceito expressa o resultado de estratégias comportamentais individuais frente a um grupo (Bowles \& Gintis, 2003; Noë, 2006). Muitos organismos desenvolvem essas estratégias comportamentais cooperativas, o que tem se apresentado como um desafio para a teoria evolutiva. Partindo do pressuposto que as bases das interações sociais apresentam probabilidades, é possível desenvolver modelos que demonstrem a cooperação como uma estratégia evolutivamente estável (Vicent \& Brown, 1988). Alguns modelos mostram que, mesmo começando num mundo onde não exista uma estrutura social, após interações os organismos passam a cooperar (Axelrod \& Hamilton, 1981; Vicent \& Brown, 1988).

\subsection{Teoria dos jogos e comportamento humano}

A análise da Teoria dos Jogos propostas por von Neumann \& Morgenstern em 1944 tem fornecido um arcabouço teórico para a investigação de interações estratégicas entre agentes em situações de conflito ou de cooperação (Axelrod, 1984; Maynard Smith, 1982). Nesse contexto, nas últimas décadas diversos jogos foram desenvolvidos e aplicados exaustivamente para investigar os processos subjacentes a tomada de decisão de agentes racionais sobre recursos comuns (Ostrom et al., 1999). Recentemente, alguns pesquisadores têm utilizado este tipo de experimento para abordar o estudo do comportamento humano em tomadas de decisões. De uma forma geral, nesses tipos de jogos os jogadores têm que decidir se cooperam ou não com seu 'oponente' a fim de aumentar seus ganhos pessoais, ao mesmo tempo em que um problema coletivo deve ser resolvido (Maynard-Smith, 1982; Nöe, 2006).

A ideia presente na economia clássica diz que os seres humanos são absolutamente racionais nas suas escolhas, ou seja, buscam maximizar seus ganhos ou benefícios (Hardin, 1968), como a procura pelos preços menores, por exemplo. Na 
teoria dos jogos, os indivíduos interagem diretamente e o resultado depende da escolha mútua dos indivíduos, por isso há uma maior complexidade envolvida, fornecendo uma metáfora para as interações na sociedade do dia a dia (Carvalho, 1975; Figueiredo, 1972; McNamara, 2004 et al., Dai \& Lu, 2015).

\subsubsection{Breve histórico da Teoria dos Jogos}

Registros antigos sobre teoria dos jogos remontam ao século XVIII, fazendo alusões a Nicolas Bernoulli (1687-1759) e James Waldegrave (1684-1741) ao analisarem um jogo de cartas cuja a solução é um equilíbrio de estratégias mistas (escolhas com base em probabilidades). No início do século XIX, em 1913, Ernst Zermelo (1871-1953) publicou o primeiro teorema matemático analisando jogos de xadrez (Sartini, et al., 2004).

Em 1928, considerado o ponto inicial dos estudos sobre Teoria dos Jogos, foi quando John von Neumann (1903-1957), matemático húngaro-americano, demostrou o teorema do 'minimax' (sempre existe uma solução racional para um conflito bem definido entre dois indivíduos, cujos interesses são completamente opostos, ou seja, o que é ganhado por um lado é perdido pelo outro) (Carvalho, 1957; Chen, 2011; Griffin, 2012). Entretanto, a Teoria dos jogos só ganha uma notoriedade em meados da década de 1940, com a proposta de análise do comportamento econômico e com a fusão das pesquisas de von Neumann e Oskar Morgenstern (1944), evidenciando o comportamento da economia como dependente das interações entre os agentes, uma vez que afetam diretamente e mutuamente a elaboração de suas estratégias além das tomadas de decisões. Com essas proposições, houve uma reformulação na teoria econômica (Chen, 2011; Griffin, 2012). Além da aplicação da Teoria dos Jogos na economia, estudos utilizando-a para encontrar as melhores estratégias a serem aplicadas em jogos de azar (onde os jogadores dependem de habilidade e de sorte) passam a ser desenvolvidos (Chen, 2011; Griffin, 2012).

A partir da década de 1950, a Teoria dos jogos é inundada por contribuições de diversos autores, mediante novos recursos para sua análise. Como exemplo, podemos citar os estudos de John F. Nash (1928-2015), matemático estadunidense vencedor do prêmio Nobel em 1994 com sua tese publicada no ano de 1951 (Non-Cooperative Games), tornando-se um dos principais nomes da história da Teoria dos Jogos (Chen, 
2011; Griffin, 2012). Atualmente, pode-se defini-la como a teoria dos modelos matemáticos que estuda a escolha de decisões sob condições de conflito, tendo o conjunto de jogadores como elemento básico, onde cada um apresenta um arsenal de estratégias (Carvalho, 1957; Osborne, 2000; Chen, 2011).

Em algumas situações de tomada de decisão pode ser expresso o comportamento onde os agentes presam mais por seus ganhos pessoais, em detrimento aos ganhos coletivos, estabelecendo-se um dilema social (Hardin 1968). Nestes dilemas, a racionalidade individual tipicamente leva à irracionalidade coletiva: cada indivíduo recebe um maior retorno para uma escolha social egoísta, embora coletivamente a cooperação seja mais vantajosa aos indivíduos de um grupo (Kollock, 1998). Admite-se que grande parte dos problemas agudos da sociedade atual resulte de tais impasses, e a expressão "tragédia dos comuns" (Hardin, 1968) foi cunhada para descrever situações em que as pessoas são incapazes de conservar um bem comum.

Podemos identificar duas categorias de jogos: cooperativos e não-cooperativos. Jogos cooperativos são aqueles em que os acordos entre os agentes são permitidos e estabelecem a base para a cooperação, visando fins específicos. Por outro lado, a estrutura dos jogos não-cooperativo não permite que acordos sejam feitos entre os agentes e lida, em grande parte, com o modo como indivíduos racionais interagem entre si e buscam atingir seus objetivos individuais (Carvalho, 1957; Figueiredo, 1972; Osborne, 2000; Sejwal, 2014). A tomada de decisão deve ser feita considerando as decisões tomadas pelos outros agentes, permitindo, assim, obter o melhor resultado possível (Carvalho, 1957; Osborne, 2000; Chen. 2011; Griffin, 2012).

\subsubsection{Dilema do Prisioneiro}

O dilema do prisioneiro é um famoso problema da Teoria dos Jogos, que relata uma situação em que dois criminosos são presos por cometerem um crime. A polícia tem evidências para mantê-los presos por um ano, porém, não para condená-los a um tempo maior. Dessa forma, os presos são colocados em selas separadas, para que não existam acordos entre eles, e recebem a proposta podendo confessar ou negar o crime. Assim, a consequência das decisões tomadas é contingente ao produto da colaboração ou não colaboração entre os criminosos. A tomada de decisão é simultânea, sendo que um não sabe sobre a decisão do outro, de forma que o prisioneiro possa satisfazer ao seu 
próprio interesse, negando o crime, ou atender ao interesse do grupo e confessar (Figura 1). Assim, o dilema do prisioneiro é um jogo não cooperativo "um jogo no qual os jogadores tomam decisões independentes visando seu benefício pessoal” (Chen, 2011).

Com a figura 1 podemos observar que uma escolha unilateral não é o melhor para ambos os prisioneiros. Caso os dois criminosos confessem o crime, ambos serão condenados a cinco anos de prisão, enquanto que se os dois negarem o crime, a condenação será de apenas 1 ano. Ainda, para um criminoso alcançar a liberdade é necessário a sua confissão, acompanhada da não confissão do outro criminoso. Desta forma, ao buscar a sua melhor situação possível para qualquer estratégia (confessar ou não confessar) do adversário, um criminoso escolherá confessar, o que caracteriza essa estratégia como dominante, pois apresenta a melhor situação possível individualmente.

Prisioneiro A

Colaborar

Trair

(Negar o Crime) $\quad$ (Confessar o Crime)

\begin{tabular}{|c|c|c|c|}
\hline & $\begin{array}{c}\text { Colaborar } \\
\text { (Negar o Crime) }\end{array}$ & 1 ano & 10 anos \\
\hline Prisioneiro B & $\begin{array}{c}\text { Trair } \\
\text { (Confessar o Crime) }\end{array}$ & Livre & 5 anos \\
\hline
\end{tabular}

Figura 1. Opções fornecida a cada um dos prisioneiros (criminosos) e resultados para combinações das possíveis tomada de decisão. Para o prisioneiro A, os valores de suas possíveis condenações estão em vermelho e acima, já os valores para B estão em azul e abaixo.

\subsubsection{Equilíbrio de Nash}

Por meio dos estudos de von Neumann e Morgenstern (1944), foram resolvidos os jogos não-cooperativos (as tomadas de decisões dos agentes são independentes) e de rivalidade, ou seja, de soma zero, onde a magnitude do ganho de um jogador representa, necessariamente, a mesma magnitude da perda para o outro jogador. Posteriormente, Nash ampliou o teorema de 'minimax' para jogos de soma não-zero, envolvendo dois ou mais jogadores em jogos não-cooperativos (Osborne, 2000; Sartini, 2004; Oliveira 2010), de forma que seu teorema pode ser aplicado a qualquer tipo de jogo não- 
cooperativo em que os jogadores disponham de um número finito de decisões, apresentando uma estratégia de equilíbrio. Para que o equilíbrio ocorra é necessário que os agentes sejam racionais, tendo seu objetivo bem definido e devendo utilizar da melhor estratégia para alcançar seu maior rendimento. O segundo pressuposto é que não exista comunicação antes e durante a interação do jogo, a fim de evitar acordos (Osborne, 2000; Sejwal, 2014). Com isso, se a escolha de cada jogador for buscando maximizar seus resultados independente da escolha dos outros, teremos o equilíbrio de Nash (Osborne, 2000; Sartini, 2004).

Como exposto, no exemplo da figura 1 é esperado que ambos os prisioneiros escolham a estratégia de 'confessar' (trair o companheiro), buscando a melhor opção para si. Entretanto, o resultado das decisões em conjunto será a pena de cinco anos de prisão para cada prisioneiro. Dessa forma, a estratégia trair-trair é o equilíbrio do jogo ou equilíbrio de Nash, sendo a solução racional desse jogo. Contudo, o dilema do prisioneiro apresenta um equilíbrio ineficiente, uma vez que os incentivos propostos juntamente com a racionalidade não induzem ao melhor resultado para ambos (Osborne, 2000; Sejwal, 2014).

Inicialmente, o ponto de equilíbrio de Nash era usado apenas para jogos com informação completa, onde todos os jogadores conhecem as estratégias de outros jogadores (Osborne, 2000; Sejwal, 2014). Entretanto, em trabalhos posteriores, o ponto de equilíbrio passou a ser usado em jogos de informação incompleta, onde as estratégias de outros jogadores não são totalmente conhecidas (Osborne, 2000; Sartini, 2004; Sejwal, 2014). A partir desses trabalhos, a Teoria dos Jogos passa a ser explorada por diversas áreas do conhecimento como economia, biologia, ciências políticas, antropologia, sociologia e direito (Osborne, 2000).

\subsubsection{Jogos finitos e infinitos}

Seguindo o exemplo proposto acima, onde o equilíbrio de Nash se dará na estratégia trair-trair (ambos confessando o crime), se algum contato entre os prisioneiros fosse permitido ocorreria, de certa forma, uma elaboração da estratégia feita por eles, podendo levar à cooperação mútua, pois é a situação de menor perda ao grupo. A cooperação também pode ser alcançada com a repetição desse tipo de jogo por diversas vezes. Os jogadores racionais podem observar as estratégias e, ao longo das interações, 
passam a cooperar mutuamente (Axelrod, 1984; Osborne, 2000) chegando ao que é denominado de quase equilíbrio, pois por maior que sejam os benefícios ao grupo, a opção de não cooperar ainda é presente e ao longo das interações ainda pode surgir vinda de algum lado. Se houver uma traição por um lado do equilíbrio, é esperada a quebra da confiança entre os envolvidos, podendo chegar a deserções mútuas, quando postos a repetir as interações (Axelrod, 1984; Milléo Filho, et al., 2004).

Em 1984 Robert Axelrod estudou estratégias para o dilema do prisioneiro iterado, ou seja, repetido diversas vezes. Nessas repetições era esperado que ocorresse uma memória da última interação, o que poderia determinar uma nova tomada de decisão. Neste sentido, foi proposto um torneio de dilema do prisioneiro iterado, onde foram apresentados diversos algoritmos de modelos comportamentais (Axelrod, 1984). O grande achado de Axelrod foi que, ao repetir diversas vezes este tipo de jogo, as estratégias denominadas egoístas tinham pior desempenho frente às estratégias denominadas altruísticas (quando havia cooperação mútua). Esse processo de interação estratégica permite que se construa uma história entre os participantes, que podem estabelecer uma reputação de cooperação, induzindo desta maneira, o desenvolvimento de estratégias semelhantes. Uma vez que a previsão de novas rodadas motiva a cooperação, o que levaria um jogador a cooperar na última rodada? Assim, ao estudar o dilema do prisioneiro iterado é necessário levar em conta se o jogo tem um fim préestabelecido. Jogos finitos são aqueles onde cada participante se depara com um conjunto finito de escolhas, já no jogo infinito ou com fim incerto, o conjunto de alternativas não tem fim determinado e há incerteza do fim do processo, o que pode manter a cooperação (Nowak, 2012).

\subsubsection{Tipo de estratégia}

Dentro de um jogo, cada jogador tem ações a serem realizadas que podem levar a diferentes resultados, sendo cada uma destas ações denominada como uma estratégia. Os jogadores têm interesses ou preferencias individuais para cada situação no jogo, o que pode ser compreendido em termos matemáticos como cada jogador tendo uma função, que atribui um número real a cada situação do jogo (Dutta, 1999; Rasmusen, 2006). Dificilmente um jogador terá apenas uma única estratégia e, assim, de posse de um conjunto de estratégias ele escolhe a melhor para determinada situação. Dentro de um jogo busca-se uma estratégia que traga as maiores recompensas ou, no mínimo, 
reduza as perdas (Hardin, 1968). As estratégias podem ser dominadas ou dominantes. Uma estratégia dominante seria aquela que sempre vai ser a melhor resposta contra qualquer estratégia do jogador oponente. Em contrapartida, uma estratégia dominada sempre vai ser a pior resposta contra qualquer estratégia do oponente.

Como vimos anteriormente na Teoria dos Jogos, a estratégia de 'trair' é considerada a estratégia dominante e independe da escolha do outro. No exemplo supracitado da figura 1, ambos os prisioneiros devem escolher a opção de confessar o crime. Entretanto, é esperado que o equilíbrio se modifique ao aumentar o número de interações (Axelrod, 1984; Milléo Filho, et al., 2004), evidenciando que em jogos com mais de uma interação existem diversas estratégias que podem ser utilizadas pelos jogadores.

Um jogo dentro da Teoria dos Jogos é uma situação de competição ou cooperação com um objetivo específico. Um jogo não ocorre apenas por acontecer, ele precisa de algo que de fundamentação, um objetivo para os jogadores (Hardin, 1968; Dutta, 1999; Milléo Filho, et al., 2004). A recompensa é representada por meio de uma função denominada utilidade, de modo que podemos pensar na recompensa de formas diversas. Numa situação entre duas empresas competindo pelo mercado de determinado produto, a recompensa pode ser estabelecida como proporção de domínio do produto no mercado. Em uma guerra, podemos pensar na recompensa como a vitória sobre os inimigos ou até mesmo o menor custo necessário para vencer. Na Biologia, em uma competição por alimento entre determinados indivíduos de uma mesma espécie, a recompensa pode ser vista como a fração de alimento obtida.

A seguir iremos exemplificar algumas das principais estratégias que podem ser utilizadas para a resolução do dilema do prisioneiro iterado:

Nunca Coopera: Independente do que o oponente faça, o indivíduo nunca irá cooperar. Esta estratégia tende a ser bastante eficaz quando usada frente a um jogador que sempre coopera, maximizando o resultado para um jogador em detrimento do outro.

Sempre Coopera: Independente do que o oponente faça, o indivíduo sempre irá usar a estratégia de cooperar. A vantagem desta estratégia é que ela terá uma alta recompensa ao grupo se ambos a adotarem de forma simultânea.

Olho por olho (Tit for Tat): Nesta estratégia, inicia-se cooperando na primeira rodada e nas rodadas seguintes adota-se a estratégia que o oponente realizou na rodada 
anterior, utilizando a não cooperação como uma forma de punição. Esta estratégia obtém alto sucesso no ambiente do dilema dos prisioneiros iterado (Axelrod, 1984; Hirshleifer \& Coll, 1988).

Grim ou Rancorosa: Nesta estratégia inicia-se com cooperação e, caso o oponente não coopere em alguma rodada, na estratégia rancorosa o jogador nunca mais irá cooperar a partir da rodada seguinte. Espera-se que esta estratégia consiga um alto valor de recompensa entre jogadores que a escolhem (Axelrod, 1984; Hirshleifer \& Coll, 1988).

\subsection{Tomada de decisão}

O estudo da tomada de decisão tenta entender nossa capacidade fundamental de processar várias alternativas e escolher um curso de ação ideal. Historicamente, a maioria das pesquisas sobre tomada de decisão examinou decisões individuais, nas quais devemos considerar puramente nossos próprios valores e preferências para selecionar uma opção (Loewenstein, et al.1989; O'Fallon \& Butterfield, 2005). No entanto, dado que vivemos em ambientes sociais altamente complexos, muitas de nossas decisões mais importantes são tomadas no contexto de interações sociais, sendo elas adicionalmente dependentes das escolhas concomitantes de outros (Sanfey 2007). Essas decisões sociais podem ser definidas como decisões que afetam os outros, assim como a nós mesmos, e são, portanto, tipicamente informadas por preferências pessoais e de outras pessoas (Fehr \& Camerer 2007). Encontramos diariamente esses cenários de decisão social: Devo confiar nessa pessoa? Devo retribuir a confiança dessa pessoa? Devo tratar essa pessoa de maneira justa? E devo respeitar as normas sociais?

As decisões sociais podem envolver conflitos entre recompensas de curto prazo e recompensas mais distantes, mas potencialmente maiores. Assim, devemos nos perguntar se estamos dispostos a suportar os custos imediatos do altruísmo para colher os benefícios a longo prazo de um relacionamento cooperativo sustentado. Finalmente, um tema mais abrangente diz respeito à tensão entre razão e emoção ao tomar decisões. Finalmente, como nas decisões, seja coletiva ou individual afetam emoções e nossa razão (Frith \& Singer 2008, Sanfey et al. 2006). De fato, razão e emoção interferem em nossas tomadas de decisão social. As emoções sociais geralmente nos ajudam a tomar decisões mais adaptativas do que seria possível apenas com o raciocínio (Damasio 
1995, Frank 1988). Embora as decisões sociais sejam importantes, é difícil recriar um cenário interativo dentro de um laboratório. Dessa forma, estudos de tomadas decisão utilizam de ferramentas matemáticas como a teoria dos jogos, como visto anteriormente.

\subsection{Ocitocina e comportamentos pró-sociais}

Pesquisas em seres humanos vêm demonstrando a participação da ocitocina como neuromodulador de alguns elementos presentes no comportamento social, como a formação de vínculos e o desenvolvimento de confiança (Kosfeld, et al., 2005), o reconhecimento de faces e suas emoções (Domes, et al. 2007), a formação de memória e aprendizagem (Heinrichs et al., 2003; Donaldson \& Young, 2008), bem como do comportamento altruísta (Zak, et al., 2007). Ainda, estudos também demonstraram a sua participação no aumento da interação social (Viero, et al., 2010) e na diminuição das respostas do organismo ao estresse (Lee, et al., 2009), colocando a ocitocina como um importante neuromodulador do comportamento.

Corroborando essa visão, estudos têm investigado seu papel na promoção de comportamentos pró-sociais por meio de jogos que exigem cooperação (Kosfeld, et al., 2005; Zak, et al., 2007). Esses estudos sugerem que a ocitocina afeta a aceitação de riscos sociais decorrentes de interações interpessoais, o que vai de encontro com os achados de pesquisas com animais, que sugerem o envolvimento da ocitocina nas bases biológicas do comportamento pró-social (Zak, et al., 2007; Donaldson \& Young, 2008).

Os estudos em animais contribuem para elucidar os mecanismos pelos quais a ocitocina pode modular a cognição social. Sua participação em comportamentos prósociais provavelmente está relacionada à distribuição de receptores ocitocinérgicos e às projeções dos neurônios ocitocinérgicos parvocelulares hipocampais para áreas associadas a esses comportamentos, bem como à ansiedade e ao medo tais como a amígdala, córtex pré-frontal e hipocampo (Viero et al. 2010; Boccia et al., 2013; Quintana et al., 2015). Como descrito por Larry e colaboradores (2015), a ocitocina regula a relação sinal-ruído do hipocampo em achados de ressonância magnética funcional, para sintonizar a atenção a estímulos socialmente relevantes em camundongos. Ainda, os receptores ocitocinérgicos, localizados em regiões colinérgicas no cérebro de primatas, modulam a atenção visual e auditiva, importantes para o processamento social sensorial. Pesquisas genéticas mostram que a ativação aguda de 
receptores da melanocortina-4 (MC4R) em ratos mutantes resgata déficits sociais neste modelo. Além disso, o tratamento agonista deste receptor potencializa a liberação de ocitocina nos centros de recompensa, como o corpo estriado ventral, facilitando a fixação social mediada pela ocitocina em ratos.

A ocitocina é uma substância peptídica composta por uma cadeia com nove aminoácidos. Sua arquitetura estrutural e funcional é bastante preservada entre as espécies de vertebrados, embora existam algumas variabilidades (Neumann, 2008; Campbell, 2010). Ambos os sexos possuem receptores para ocitocina, tanto no sistema nervoso central como no periférico. Entretanto, sua expressão tem relação com o nível de estrógenos (McCarthy, et al., 1996; Lim \& Young, 2006). Apesar de ser encontrada em ambos os sexos, os efeitos da ocitocina são mais comumente estudados em homens, pois parte do hormônio ministrado intranasalmente atinge a corrente sanguínea, potencializando seus efeitos periféricos, o que pode acarretar em riscos envolvendo períodos gestacionais e, assim, a necessidade de um maior controle das variáveis envolvidas (Campbell, 2010).

A escolha pela via nasal para a administração da ocitocina se deve à presença da barreita hematoencefálica, que é uma interface que medeia o fluxo de substâncias entre a corrente sanguínea e o parenquima cerebral, constituindo-se de uma barreira seletiva às substâncias que a atravessam em direção ao sistema nervoso central (de Paula Le Sueur, et al., 2003). Por isso, o hormônio ocitocina tem extrema dificuldade de entrar no sistema nervoso central a partir da circulação sanguínea, o que faz da administração intranasal uma alternativa potencialmente promissora para alcançar seus efeitos centrais, uma vez que existe um caminho direto entre o neuroepitélio olfatório e o cérebro. A mucosa nasal é a única localização do corpo que proporciona essa relação entre o sistema nervoso central e o meio ambiente (Wang, et al., 2013; Guastella, et al., 2013). Assim, um número crescente de estudos têm utilizado a ocitocina intranasal para investigar seus efeitos sobre os mecanismos neurais envolvidos no comportamento e cognição social, após a descoberta de que a administração intranasal de neuropeptídeos pode atingir o sistema nervoso central (Kirsch, 2005; Petrovic, et al., 2008; Singer et al., 2008; Wang et al., 2013).

Em revisão recentemente realizada por Quintana e colegas em 2015, os autores sinalisaram as seguintes rotas para a ocitocina, após administração intranasal: (1) via vasculatura nasal para a circulação sistêmica; (2) via nervo olfatório para o bulbo 
olfatório e diretamente para o líquor e cérebro, inclusive por meio do fluído linfático circundante; e (3) via nervo trigêmeo para o tronco cerebral (Figura 2). Além disso, a ocitocina inalatória pode provocar alguns de seus efeitos no sitema nervoso central ao estimular o sistema ocitocinérgico endógeno, que secreta ocitocina na circulação periférica, bem como a distribui pelo sistema nervoso central via alvo sináptico e liberação dendrítica, ou até mesmo através de difusão a partir dos sítios de liberação hipotalâmicos (Stoop, 2012). Outras possíveis rotas foram descartadas, como por exemplo pelo epitélio alveolar dos pulmões, uma vez que as moléculas de ocitocina são muito grandes (1007 Daltons) para serem absorvidas por esse epitélio, adaptado para captar peptídeos menores do que 30 Daltons (Imgartinger, et al., 2004).

As moléculas de ocitocina podem atravessar o epitélio olfatório tanto por via extracelular (por difusão paracelular), como por via intracelular (por endocitose realizada pelos neurônios sensoriais) (Jasson \& Björk, 2002). A via periférica (via extracelular) envolve a transferência do fármaco intranasal para a circulação sistêmica, sendo absorvido através do epitélio por uma rede de capilares sanguíneos fornecidos pelas artérias carótidas interna e externa, localizados abaixo da membrana da cavidade nasal, nos epitélios olfatório e respiratório. Uma vez que as moléculas atingem a lâmina própria destes epitélios por difusão paracelular, elas podem entrar na circulação sistêmica através dos capilares capazes de captar grandes moléculas. Essa absorção ocorre, na maior parte, por meio do fármaco que permanece anteriormente à válvula nasal (Figura 2) (Wolburg, et al., 2008; Guastella, et al., 2013; Quintana et al., 2015). Embora a ocitocina circulando sistemicamente não atravesse com facilidade a BHE, ela possui acesso aos seus receptores em órgãos como o coração, pulmões e rins, podendo exercer diversos efeitos periféricos como enviar sinais ao sistema nervoso central (Gimpl \& Fahrenholz, 2001). O aumento nos níveis centrais de ocitocina após a administração intranasal pode, indiretamente, ocorrer por meio desses sinais, estimulando a liberação endógena para o sistema nervoso central, bem como para a circulação sistêmica (Striepens, et al., 2013).

Pela via olfatória (via intracelular), a ocitocina inalada além da válvula nasal é captada pelos neurônios olfatórios presentes no epitélio olfatório, os únicos neurônios sensoriais que possuem seus corpos expostos ao meio ambiente, e em seguida é transferida através do epitélio, via nervo olfatório, para o bulbo olfatório (Figura 2) (Quintana et al., 2015), de onde pode ser transferida para o líquido cefalorraquidiano 
(LCR) (Bahadur \& Pathak, 2012). Vale lembrar que os axônios do córtex olfatório primário projetam-se para núcleos na amígdala e hipotálamo (Jolkkonen, et al., 2001; Kang, et al., 2011), indo ao encontro de estudos que demonstram o impacto funcional da administração intranasal de ocitocina sobre o processamento neural em humanos (Kirsch, et al., 2005). A via olfatória potencialmente proporciona o caminho mais direto para a absorção da ocitocina pelo sistema nervoso central.

O trajeto por meio do nervo trigêmeo também teve crescente reconhecimento como possível rota das moléculas administradas via intranasal para o sistema nervoso central (Thorne, et al., 2004; Guastella, et al., 2013). Entretanto, estudos com seres humanos que caracterizam a absorção por esta via ainda são escassos. A via trigeminal consiste em fibras nervosas aferentes trigeminais que inervam amplamente o epitélio olfatório e respiratório da cavidade nasal, projetando-se para núcleos no tronco encefálico (Figura 2) (Anton \& Peppel, 1991). Quintana e colaboradores discutem que muitos outros produtos administrados por via intranasal, como a lidocaína, células estaminais e inibidor da telomerase, por exemplo, foram relatados alcançando o tronco encefálico de roedores por meio de fibras nervosas trigeminais, embora seja possível que tais substâncias cheguem ao tronco encefálico por outros mecanismos como a difusão através do epitélio olfatório. Projeções da amígdala e núcleo paraventricular hipotalâmico estendem-se aos núcleos no tronco encefálico que regulam a atividade cardíaca (Viviani, et al., 2011). Além disso, a via olfatória e trigeminal estão relacionas funcionalmente, uma vez que há vias aferentes tanto do tronco encefálico como do bulbo olfatório para o núcleo hipotalâmico paraventricular (Meddle, et al., 2000). 


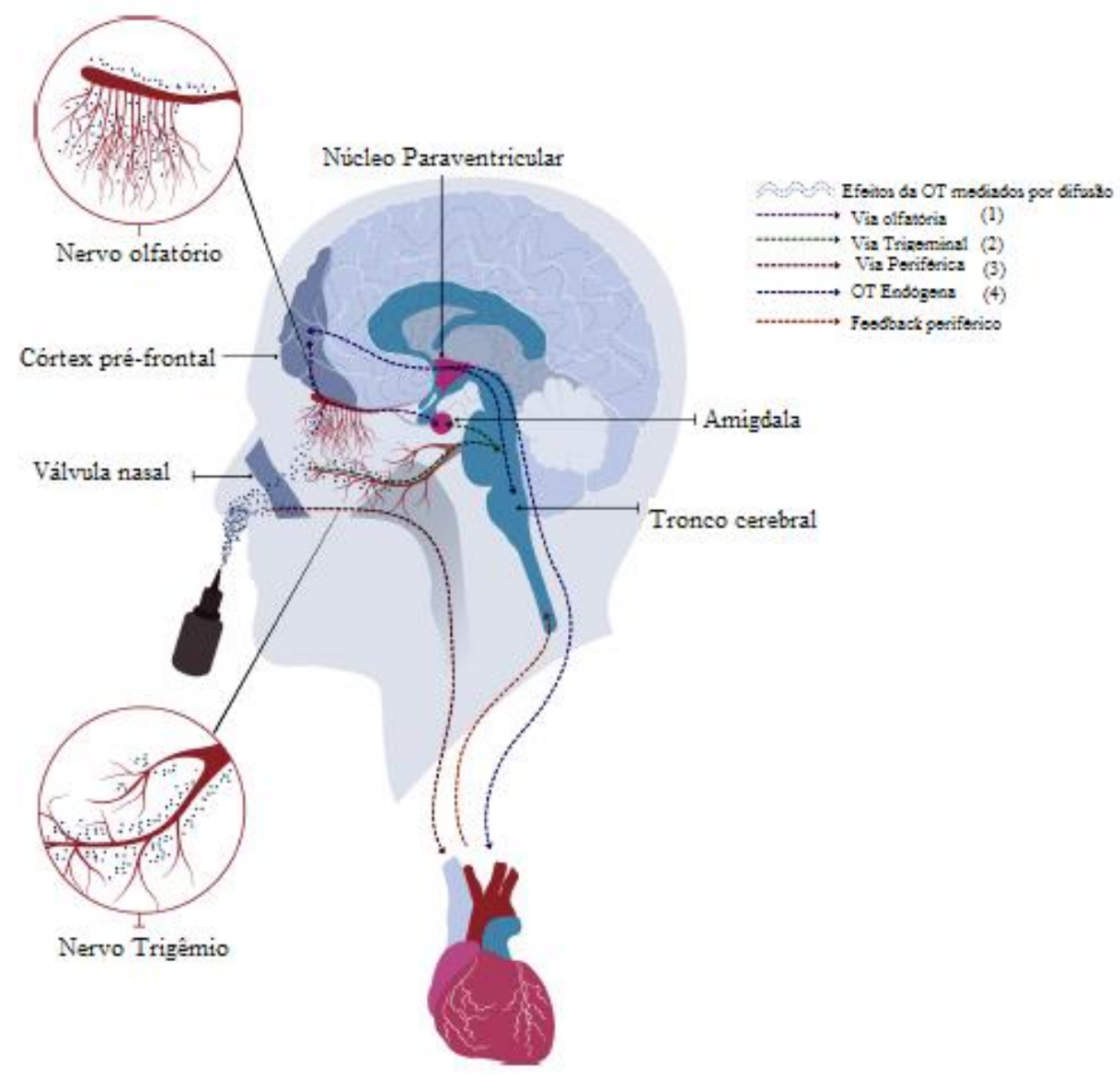

Figura 2. Representação das possíveis rotas e destinos da ocitocina inalatória. Para a amígdala, através do bulbo olfatório e, em seguida, por meio de projeções axonais, bem como por difusão através do líquido cefalorraquidiano (LCR) (1); para o tronco encefálico, por meio de fibras nervosas trigeminais (2); para a periferia, por meio de capilares sanguíneos presentes no epitélio olfatório e respiratório (3). A absorção de ocitocina pelas vias olfatória e trigeminal pode estimular sua produção endógena pelo núcleo paraventricular (PVN), que possui projeções ocitocinérgicas para o córtex pré-frontal e tronco encefálico, bem como para a circulação sistêmica (4). (Adaptada de Quintana et al, 2015).

Considerando o envolvimento da ocitocina com vários elementos da cognição social e o interesse em compreender aspectos sociais e biológicos do comportamento social, bem como em melhorar a função social, o estudo da participação da ocitocina nesse cenário por meio de modelos comportamentais baseados na teoria dos jogos, torna-se uma estimulante ferramenta de investigação. 


\section{Objetivo}

Este estudo teve como objetivo geral investigar a influência da ocitocina sobre a confiança adquirida entre jogadores no processo de tomada de decisão, frente a um jogo sequencial inspirado no dilema do prisioneiro iterado.

Para tanto, os objetivos específicos foram: (1) desenvolvimento de um software, na linguagem "Phyton”, para a aplicação do jogo de uma forma automatizada; (2) análise do efeito da ocitocina sobre o número de cooperações ao longo do jogo; (3) análise do efeito da ocitocina sobre a relação entre as sequências das respostas de cooperação ou não-cooperação; (4) análise da interferência do estado de humor na tomada de decisão (coopera, não coopera), sob o efeito da ocitocina. 


\section{Metodologia}

\subsection{Sujeitos}

Oitenta (80) estudantes universitários do sexo masculino, com idades variando entre 19 a 45 anos $(M=22,317, D P=3.972)$, participaram do experimento de forma voluntária. O recrutamento dos voluntários foi realizado por convites enviados a todos os alunos de graduação e de pós-graduação do dos Institutos de Biologia e Ciências Biomédicas da Universidade de São Paulo. Primeiramente os voluntários responderam a um questionário de avaliação geral, onde foi possível selecioná-los a partir dos critérios de exclusão pré-estabelecidos: uso de fármacos de ação no sistema nervoso central, história de doença neurológica, distúrbios psiquiátricos e uso excessivo de álcool ou de drogas (Anexo 1). Posteriormente, os voluntários foram instruídos a agendar um horário para a realização do experimento. Após esclarecimento de todos os procedimentos, o termo de consentimento livre e esclarecido (Anexo 2) foi apresentado e assinado no dia do experimento antes de qualquer intervenção, conforme resolução 196/96 do Ministério da Saúde.

\subsection{Materiais}

\subsubsection{Desenvolvimento do Jogo}

Como já exposto, o desenvolvimento do jogo para este estudo baseou-se no dilema do prisioneiro, onde dois jogadores devem escolher simultaneamente entre a opção 1 e a opção 2 (cooperar e não cooperar, respectivamente), sem que saibam da decisão do outro no momento de escolha. Logo após as escolhas serem realizadas o resultado da jogada é apresentado aos jogadores. Se a cooperação for mútua (opção 1opção 1), ambos os jogadores recebem uma quantia $b$. Se ambos não cooperarem (opção 2 - opção 2), eles recebem uma quantia $c$. Entretanto, se a decisão for diferente, aquele que cooperou recebe $d$ enquanto aquele que não cooperou recebe $a$. Assim temos que os valores $a, b, c$ e $d$ podem ser qualquer valor real desde que seja respeitado a sentença $a$ $<b<c<d$.

Neste experimento os participantes foram convidados a jogar o dilema do prisioneiro iterado para dois jogadores, podendo interagir num intervalo que variava de 
no mínimo 10 e no máximo 30 vezes, dependendo das escolhas ao longo do jogo. Foram estipulados os seguintes valores de ganhos e perdas para as interações que ocorreram: $a=4 ; b=2 ; c=-1 ; d=-2$ (figura 3), sendo que a pontuação dos valores de ganhos e perdas corresponde a unidades de chocolate Bis, da marca Lacta. Os jogadores iniciavam o jogo com uma quantia de 20 unidades de chocolate Bis, podendo acumular no máximo 80 e no mínimo zero unidades cada um, resultando no fim do jogo.

Jogador 1

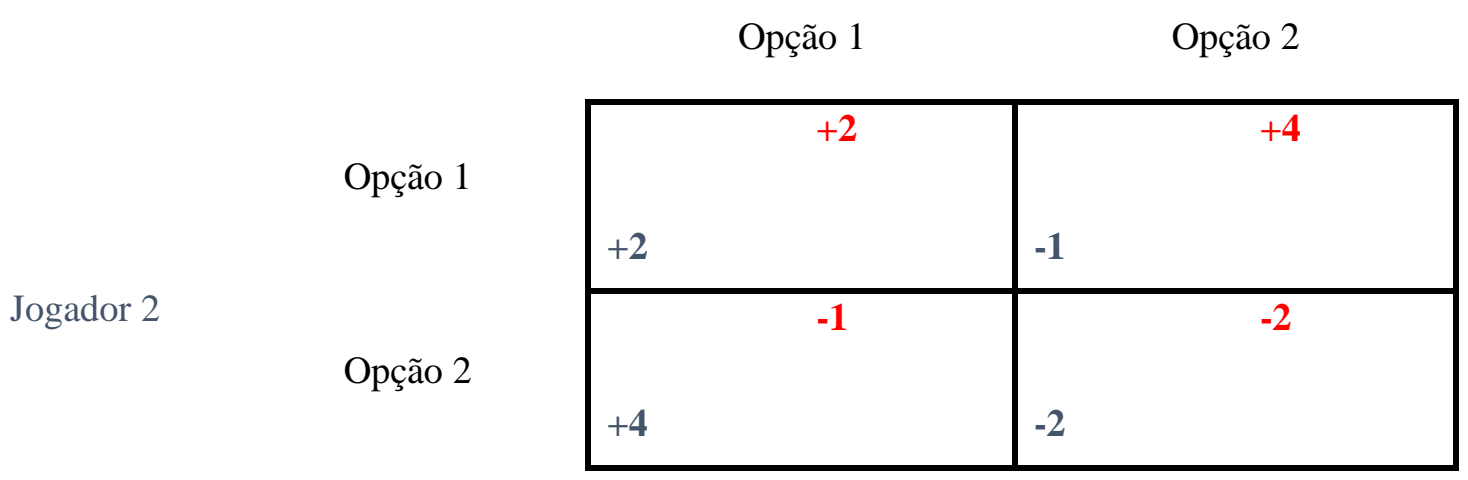

Figura 3: Tabela de ganhos ou perdas para o jogo dilema do prisioneiro iterado proposto, estabelecida pela relação entre as escolhas feitas pelos jogadores. Os valores do jogador 1 estão em vermelho e acima, já os valores para o jogador 2 estão em azul e abaixo.

\subsubsection{Desenvolvimento de software}

Para realizar o jogo proposto acima e minimizar a intervenção humana, foi desenvolvido um software na linguagem "Phyton" para a aplicação do jogo de uma forma automatizada. A elaboração e o desenvolvimento desse software próprio foram realizados em conjunto com pós-graduando Bernard Costa, pertencente ao Laboratório de Fisiologia Sensorial "Roberto Vieira" do Instituto de Ciências Biomédicas II da Universidade de São Paulo.

Todo o desenvolvimento do jogo computacional foi baseado em duas premissas: (1) manter o anonimato dos voluntários e (2) possibilitar que as interações entre os participantes ocorressem apenas pelo jogo. Dessa forma, o software foi aberto em um computador ligado a dois monitores com suas imagens duplicadas, apresentando os mesmos estímulos a ambos os voluntários concomitantemente.

Para desenvolver o jogo computacional foi utilizado o aplicativo PsychoPy, que apresenta seus códigos abertos para desenvolvedores, permitindo que seus usuários 
executem diversos experimentos na área de neurociências, psicologia e psicofísica. A linguagem do PsychoPy pode facilmente trafegar entre as plataformas, motivo pelo qual é bastante popular em pesquisas acadêmicas, pois apresenta alta portabilidade além de uma interface gráfica amigável (figura 4).

A linguagem de programação utilizada dentro do PsychoPy em sua grande maioria é Python, sendo uma alternativa gratuita à linguagem utilizada no Matlab ${ }^{\mathrm{TM}}$ (The Mathworks Inc., Massachusetts, EUA). Apesar de muitos laboratórios usarem o Matlab $^{\text {TM }}$ como sua linguagem de programação principal, são encontradas algumas dificuldades técnicas, como por exemplo, o investimento em apenas uma plataforma - o que limita sua portabilidade, ou mesmo as resoluções de problemas que devem ser resolvidos apenas pelos desenvolvedores da linguagem, o que pode dificultar a criação de protocolos experimentais.

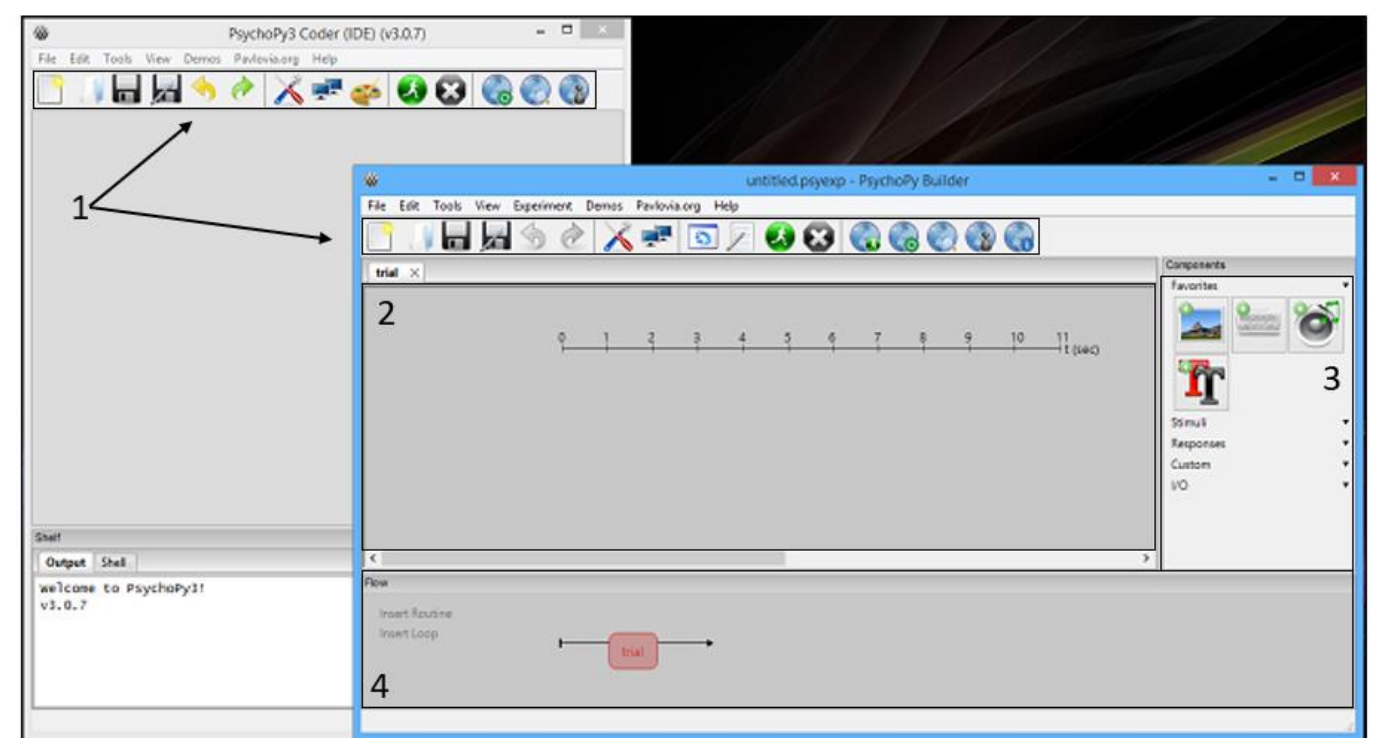

Figura 4. Interface do PsychoPy. 1 Botões que auxiliam na criação de um novo projeto até sua execução. 2 Espaço destinado ao controle de estímulos, como por exemplo tempo de duração. 3 Atalho para a rápida inserção de estímulos (imagens, sons ou textos). 4 Acompanhamento da rotina de programação criada.

Posto isto, alguns laboratórios buscam alternativas ao Matlab ${ }^{\mathrm{TM}}$, como o uso da linguagem Python. Entretanto, elas apresentam algumas diferenças importantes. O Python tem uma interface muito mais limpa tornando o código fácil de ler e encontrar erros (i.e., interface amigável), além disso, é completamente gratuita e está em desenvolvimento contínuo em todas as plataformas e, por fim, apresenta um grande conjunto de bibliotecas (i.e., OpenGL) já construídos pela comunidade que o utiliza. Dessa forma, o PsychoPy é quase todo escrito nessa linguagem. 


\subsubsection{Procedimentos experimentais}

Para o procedimento experimental, os voluntários foram levados a salas individualizadas, não apresentando qualquer contato um com o outro. Na sala de cada voluntário tínhamos um monitor de LCD de 18 polegadas à sua frente para a visualização dos estímulos, uma caixa com itens lúdicos, pastas contendo questionários e numeradas de 1 a 3 para serem utilizadas em cada etapa do experimento, uma campainha para se comunicar com o experimentador caso necessário (figura 5A) e um teclado numérico com as duas opções de escolha para as respostas do jogo (figura 5B). Os monitores estavam sempre ligados e todas as informações sobre as etapas do experimento foram passadas aos participantes remotamente, por um vídeo pré-gravado apresentado nos monitores.
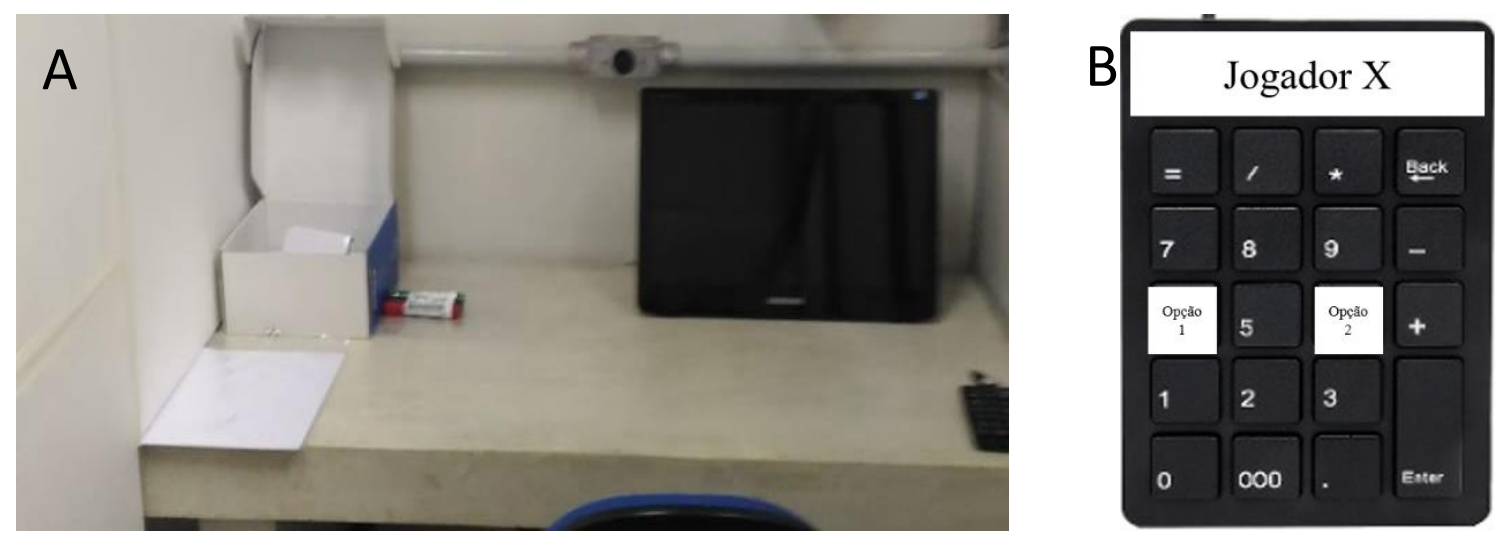

Figura 5: Disposição do setup experimental com teclado numérico à direita, monitor lcd, caixa de atividades lúdicas e questionários a serem respondido ao longo do jogo à esquerda (Imagem A). Teclado numérico contendo as teclas correspondentes às duas opções de escolha a cada rodada, utilizado durante o jogo (Imagem B).

Seguindo as orientações do vídeo, os voluntários inicialmente foram convidados a desligar e guardar o telefone celular, acomodando-se de forma confortável. Em seguida, responderam o questionário de escala de humor de $\mathrm{POMS}^{1}$ (Anexo 3), a fim de verificar e classificar como se encontrava o estado dos participantes antes do procedimento experimental. Posteriormente, os voluntários foram instruídos, via vídeo,

\footnotetext{
${ }^{1}$ O Perfil de Estados de Humor (Profile of Mood States - POMS) tem sido um dos instrumentos mais utilizados em psicologia para avaliar os estados emocionais e os estados de humor, tendo sua forma original publicada por McNair e colaboradores em 1971 e adaptada para língua portuguesa por Viana, et al., 2012.
} 
a realizar a autoadministração da substância controlada (40 UI de ocitocina ou placebo) apresentada dentro de um isopor com gelo, seguida de um tempo de espera de 45 minutos para a ação da ocitocina no sistema nervoso central. Durante esse tempo de espera, os participantes foram convidados a realizar algumas atividades neutras a fim de não alterar seu estado de humor. As atividades propostas a serem realizadas eram compostas de modelagem, pintura, jogos de cartas individuais e cruzadinhas.

Ao final dos 45 minutos, os participantes foram informados de que iniciariam sua participação no jogo com uma pontuação de 20 chocolates Bis para cada um, sendo que essa quantidade poderia aumentar ou diminuir, de acordo com as interações entre as escolhas realizadas. Foram informados também de que o jogo consistia em escolher entre duas opções (opção 1 ou opção 2) e registrar sua escolha clicando nas teclas correspondente (figura 5B).

Apesar de cada jogo ter sido constituído por um número máximo de 30 rodadas, esse valor não foi informado aos voluntários, caracterizando um jogo sem fim determinado. A cada rodada o jogador deveria tomar uma decisão sobre qual opção escolher, segundo a tabela de recompensas (figura 6 A e B), buscando a melhor estratégia que julga-se apropriada. Vale ressaltar que as telas eram mostradas espelhadas aos jogadores, assim a resposta do jogador A só é validade quando a figura 6A aparece e a resposta do jogador B só era computada com a aparição da figura 6B. No fim do jogo os jogadores ganharam as recompensas que acumularam ao longo do jogo. Por fim, os participantes responderam novamente a um questionário de humor (teste de POMS).

\subsubsection{Teste de POMS}

Um dos instrumentos mais utilizados na área da Psicologia para avaliar os estados emocionais e os estados de humor, assim como a variação que lhes está associada é o teste POMS, Profile of Mood States (Perfil dos Estados de Humor). A escala de POMS original foi inicialmente traduzida para o português por Cruz e Viana (1993) e utilizada em diversos trabalhos de avaliação psicológica, compostas por 49 adjetivos.

Este instrumento, originalmente construído para avaliar as variações dos estados de humor em populações psiquiátricas, rapidamente redirecionou a sua utilização para outras populações não clínicas sendo uma ferramenta de fácil e rápida utilização para 
captar os estados afetivos transitórios e flutuantes nos sujeitos. A versão apresentada neste trabalho é composta por 24 itens, tendo cada uma das seis escalas - Tensão, Depressão, Raiva, Vigor, Fadiga e Confusão. Os itens são respondidos numa escala do tipo Likert, em que as respostas obtidas variam numa escala de 5 pontos (0 - De maneira nenhuma; 1 - Um pouco; 2 - Moderadamente; 3 - Muito; 4 - Muitíssimo). Assim, o valor de cada escala poderia variar de 0 a 16 pontos.

\subsubsection{Rotina computacional}

A rotina do jogo foi iniciada com breves explicações sobre o jogo, retomando as explicações visualizadas durante a exposição do vídeo, de forma a especificar como o jogo ocorreria e como cada jogador deveria inserir suas respostas. Posteriormente, os jogadores colocaram suas respostas seguindo as orientações fornecidas, sendo que entre as escolhas dos jogadores e o resultado de cada jogada apresentado pelo programa ocorreu um pequeno intervalo de tempo (1 a 3 segundos), demarcado por uma tela de "aguardem". Em seguida, o programa apresentou as interações das respostas, informando quando as escolhas dos participantes haviam sido as mesmas (Figura 6C) e quando haviam sido diferentes (figura 6D), o que permitia a inferência da resposta do jogador adversário.

Essa configuração de jogo caracterizava o início de um looping de no máximo 30 rodadas. O fim do jogo poderia ocorrer de duas maneiras, não informadas aos voluntários. A primeira forma era considerada encerramento precoce, ou seja, terminar antes de atingir o planejado, o que ocorreria se e somente se algum jogador atinge-se a quantia de zero chocolates Bis em qualquer momento do jogo. A segunda maneira era a planejada, ou esperada, com o fim na trigésima rodada, onde os voluntários apresentariam quantias maiores ou igual a zero e levariam consigo suas recompensas. 


\begin{tabular}{|c|c|c|c|c|c|c|c|}
\hline \multirow[t]{2}{*}{ Escolha dos jogadores } & \multicolumn{2}{|c|}{ Situações do Jogo } & \multirow{2}{*}{ A } & \multirow[t]{2}{*}{ Escolha dos jogadores } & \multicolumn{2}{|c|}{ Situações do Jogo } & \multirow{2}{*}{ B } \\
\hline & Jogador A & Jogador B & & & Jogador $\mathbf{A}$ & Jogador B & \\
\hline $\begin{array}{l}\text { Jogador } A \rightarrow \text { Opqä́ } 1 \\
\text { Jogador } B \rightarrow \text { Opsăo } 1\end{array}$ & Ganha $2(+2)$ & Ganha $2(+2)$ & & $\begin{array}{l}\text { Jogador } A \rightarrow \text { Opgào } 1 \\
\text { Jogador B } \rightarrow \text { Opgăo } 1\end{array}$ & Ganha $2(+2)$ & Ganha $2(+2)$ & \\
\hline $\begin{array}{l}\text { Jogador } A \rightarrow \text { OpGáb } 1 \\
\text { Jogador B } \rightarrow \text { OpGâo } 2\end{array}$ & Perde $1(-1)$ & Ganha $4(+4)$ & & $\begin{array}{l}\text { Jogador } A \rightarrow \text { Opqăo } 1 \\
\text { Jogador } B \rightarrow \text { Opqaáo } 2\end{array}$ & Perde $1(-1)$ & Ganha $4(+4)$ & \\
\hline $\begin{array}{l}\text { Jogador } A \rightarrow \text { Opcăo } 2 \\
\text { Jogador } B \rightarrow \text { Opáä } 1\end{array}$ & Ganha $4(+4)$ & Porde $1(-1)$ & & $\begin{array}{l}\text { Jogador } A \rightarrow \text { Opgä́ } 2 \\
\text { Jogagdor } B \rightarrow \text { Opgáä } 1\end{array}$ & Ganha $4(+4)$ & Porde $1(-1)$ & \\
\hline $\begin{array}{l}\text { Jogador } A \rightarrow \text { Opquăo } 2 \\
\text { Jogador } B \rightarrow \text { Opq̧äo } 2\end{array}$ & Perdo $2(-2)$ & Perde $2(-2)$ & & $\begin{array}{l}\text { Jogador } A \rightarrow \text { Opgäo } 2 \\
\text { Jogador } B \rightarrow \text { Opq̧ăo } 2\end{array}$ & Pordo $2(-2)$ & Porde 2(-2) & \\
\hline \multicolumn{2}{|c|}{ • Jogador A é a sua vez... } & $\begin{array}{l}\text { - Escolha: Opção } 1 \text { ou Opção } 2 \\
\text { Apertando a tecla correspondente }\end{array}$ & & \multicolumn{3}{|c|}{$\begin{array}{l}\text { - Escolha: Opção } 1 \text { ou Opção } 2 \\
\text { Apertando a tecla correspondente }\end{array}$} & \\
\hline \multicolumn{3}{|c|}{$\begin{array}{l}\text { A escolha de cada } \\
\text { participante foi a } \\
\text { mesma }\end{array}$} & C & \multicolumn{3}{|c|}{$\begin{array}{l}\text { A escolha de cada } \\
\text { participante foi } \\
\text { diferente }\end{array}$} & D \\
\hline
\end{tabular}

Figura 6: (A e B) Telas apresentadas ao jogador A (tela A) e B (tela B) a cada tomada de decisão, contendo as tabelas de recompensa modificadas para maior compreensão dos participantes. (C e D) Telas apresentadas após a escolha feita por ambos os voluntários a cada rodada, informando a interação entre as escolhas quando eram a mesma (tela C) ou diferentes (tela D).

\subsubsection{Teste de atenção}

Antes do início do jogo, os voluntários responderam ao teste de atenção de Toulouse-Piéron (Anexo 4), com duração de cinco minutos, a fim de considerar o nível de atenção dos jogadores como variável preditora das cooperações. Entretanto, a análise das respostas não foi realizada, pois muitos voluntários não responderam corretamente, apontando possível inadequação nas instruções fornecidas pelo experimentador. Dos 60 voluntários, apenas 10 responderam corretamente.

\subsubsection{Análise Dados}

A análise dos dados que caracterizaram os dois grupos, placebo e ocitocina, considerou o número de cooperações a cada interação (rodada), bem como os montantes acumulados pelos jogadores ao longo do jogo como variáveis quantitativas. Para essa análise principal, os dados foram comparados utilizando o teste de Mann-Whitney, tendo como variável independente a pontuação final do jogo resultado no fim do jogo e a variável dependente a decisão tomada (cooperar ou não cooperar). Além disso, fizemos regressões lineares para estudar o comportamento dos grupos fazendo projeções de seus estados de cooperação e montantes, caso o jogo segue a diante. 
Também coletamos o estado de humor (variável quantitativa) dos voluntários em dois momentos (no início do experimento e no fim do experimento). Para esta análise foi realizada o teste $\mathrm{T}$ pareado comparando as situações iniciais e finais dentro de cada grupo de voluntários. Além disso, também comparamos os valores entre grupos a fim de identificar se os níveis de humor eram diferentes.

Todas as análises estatísticas foram realizadas utilizando-se o software Minitab® versão 19.1.1.0. Os gráficos apresentados foram feitos no programa Microsoft Office Excel $^{\mathrm{TM}}{ }^{\mathrm{R}}$. 


\section{Resultados}

A análise das respostas referentes ao estado de humor de cada voluntário, tomadas pela apresentação do questionário POMS, não apresentou diferenças entre o estado de humor inicial e final para as seis categorias investigadas (tensão, raiva, vigor, confusão, fadiga e depressão). Os dados foram analisados com teste t pareado. (Tabela 1). Além desta análise, comparamos os diferentes estados de humor entre os grupos, ao término do jogo, onde também não foram identificadas diferenças (tensão $\mathrm{p}=0,787$; raiva $\mathrm{p}=0,055$; vigor $\mathrm{p}=0,26$; confusão $\mathrm{p}=0,39$; fadiga $\mathrm{p}=0,955$; depressão $\mathrm{p}=$ $0,126)$.

Tabela 1: Comparação das situações inicial e final do teste de POMS. DP = Desvio padrão; $\mathrm{p}=$ valor de $\mathrm{p}$ calculado; PLC = grupo com placebo; $\mathrm{OCI}=$ grupo com ocitocina.

\begin{tabular}{lcc|cc|cc} 
& \multicolumn{2}{c|}{ Média } & \multicolumn{2}{c|}{ DP } & \multicolumn{2}{c}{$\mathrm{p}$} \\
\hline Condição & PLC & OCI & PLC & OCI & PLC & OCI \\
\hline Tensão & 0,433 & 0,167 & 3,884 & 3,343 & 0,546 & 0,787 \\
Raiva & $-0,567$ & 1,067 & 3,549 & 3,903 & 0,389 & 0,145 \\
Vigor & 0,167 & 1,367 & 4,136 & 4,056 & 0,827 & 0,075 \\
Confusão & $-0,733$ & 0,133 & 3,053 & 4,125 & 0,261 & 0,861 \\
Fadiga & $-0,167$ & $-0,1$ & 4,956 & 3,827 & 0,855 & 0,887 \\
Depressão & -1 & 0,767 & 4,283 & 4,066 & 0,211 & 0,31
\end{tabular}

Foi analisado também, o número total de cooperações para os dois grupos experimentais (figura 7), sendo maior para o grupo ocitocina quando comparado ao grupo placebo $(U=1364,50 ; p<0,001)$. No grupo ocitocina, 14 jogos chegaram ao final das 30 rodadas, enquanto que no grupo placebo, apenas 9 jogos completaram o número máximos de jogadas.

Ao analisar as cooperações numa serie temporal (figura 8) temos que o grupo placebo apresenta valores menores do que o grupo ocitocina. Além disso, a comparação das cooperações entre três períodos subsequentes de 10 rodadas, ou seja, da rodada 1 à 10 , rodada 11 à 20 e rodada 21 à 30 , nos mostrou que ambos os grupos apresentam um crescente no número de cooperação (ocitocina: $\mathrm{y}=1.8384 \mathrm{x}+64,889 ; \mathrm{R} 2=0,6196 \mathrm{e}$ placebo: $\mathrm{y}=0,5253 \mathrm{x}+54,444 \mathrm{R} 2=0,1766)$. Ao analisar as rodadas de 11 a 20 pudemos observar que a tendência do grupo ocitocina continuou numa crescente ( $\alpha=$ 


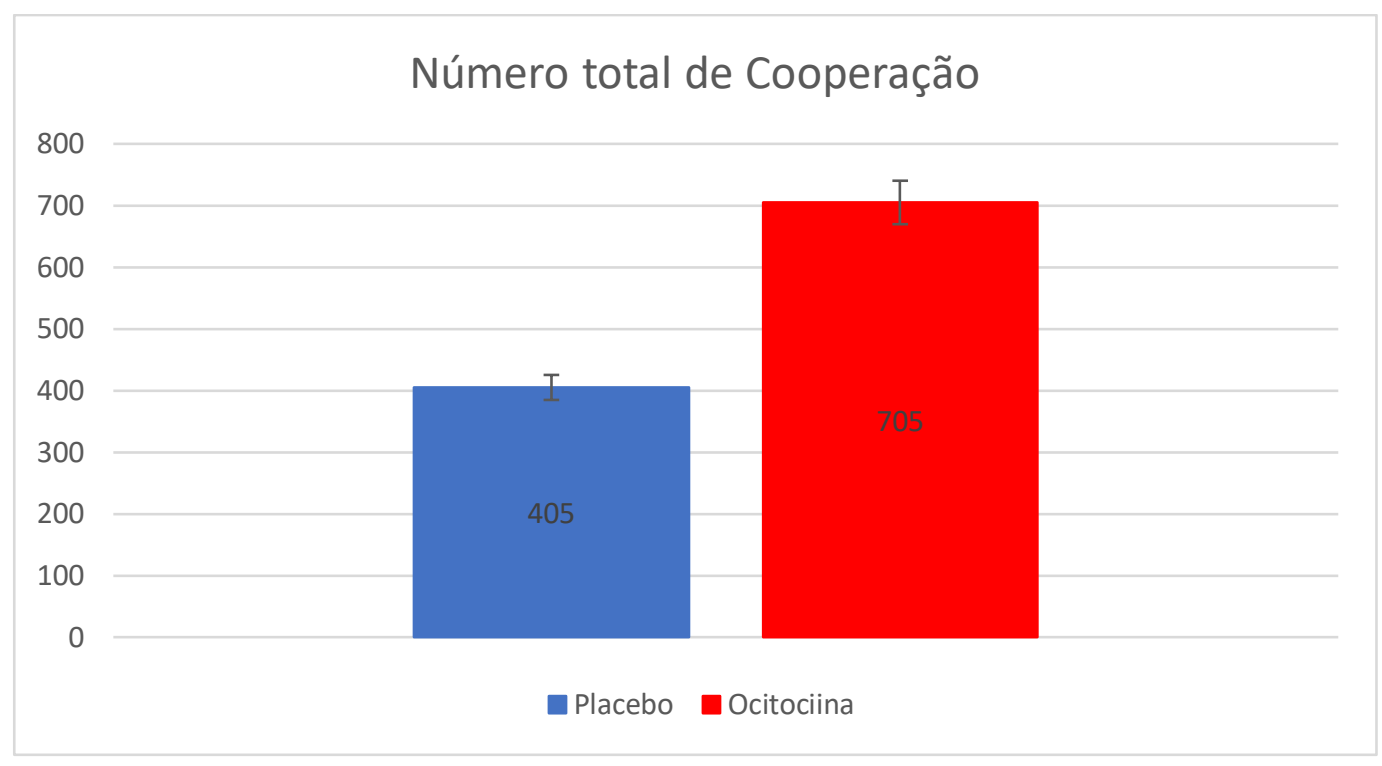

Figura 7: Total de cooperações realizadas pelos jogadores do grupo placebo e ocitocina, ao longo de todos os jogos.

0,1616), porém menor que nas primeiras rodadas. O grupo com placebo apresentou comportamento oposto, com tendência decrescente $(\alpha=-0,9311)$. No último terço, o grupo ocitocina apresentou estabilização no número de cooperação $\left(\alpha=9 \times 10^{-15}\right)$ enquanto o grupo placebo teve redução na magnitude do decréscimo $(\alpha=-0,7438)$.

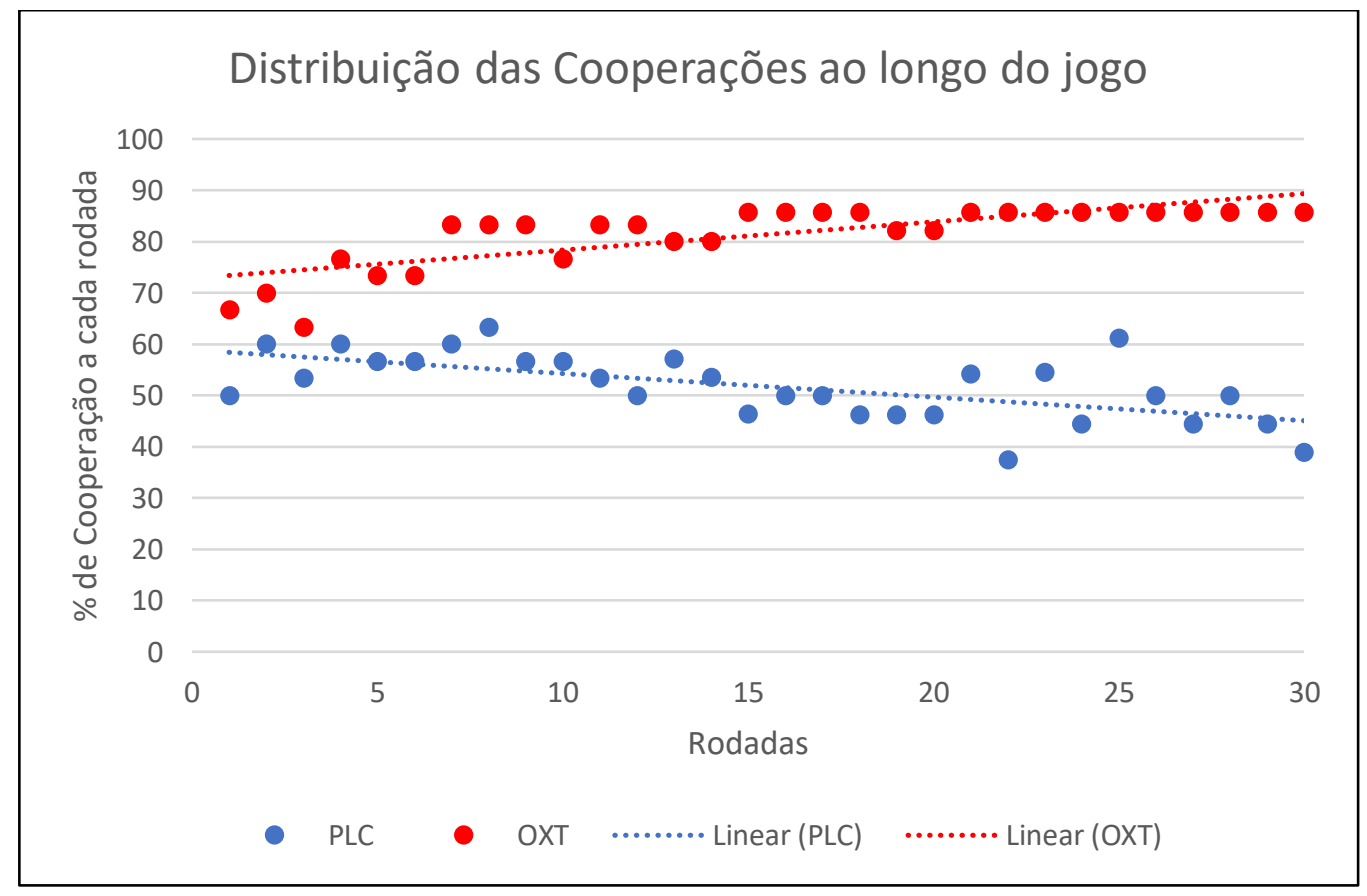

Figura 8: Porcentagem de cooperações a cada rodada para o grupo placebo e ocitocina. As linhas pontilhadas são as regressões lineares para cada grupo (placebo y $=-0,4595 \mathrm{x}+58,849$; $\mathrm{R}^{2}=0,3818$ e ocitocina $\left.\mathrm{y}=0,5501 \mathrm{x}+72,838 ; \mathrm{R}^{2}=0,6005\right)$. 
As respostas dos jogadores podem ser divididas e analisadas em função apenas do número de cooperações, mas também de acordo com a relação entre as respostas dos participantes em cada jogada, ou seja, se houve cooperação mútua ou de apenas um participante. Esses resultados são apresentados na figura 9, onde podemos observar que o comportamento de cooperações mútuas ao longo do jogo foi mais presente no grupo ocitocina, tendo em vista a porcentagem de rodadas com cooperações mútuas neste período. Além disso, nota-se uma alternância de comportamento entre as rodadas sequenciais do grupo placebo, pela flutuação percentual de rodadas com cooperação mútua.

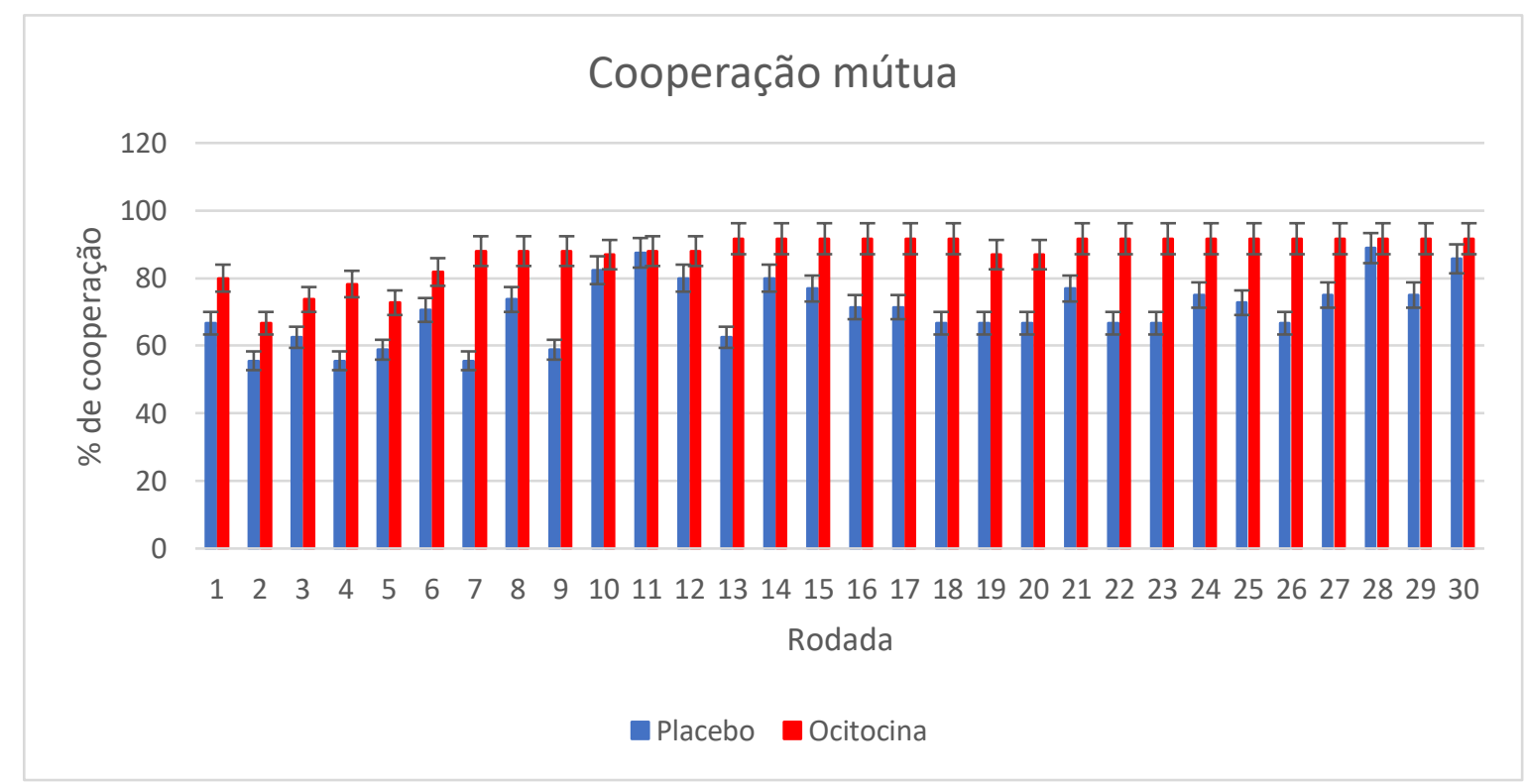

Figura 9: Porcentagem de cooperações mútuas para o grupo placebo e ocitocina, à cada rodada ao longo do jogo.

Outra análise realizada foi sobre os ganhos (pontuação) dos jogadores ao longo do jogo (figura 10), por meio da somatória dos pontos acumulados a cada rodada. Pudemos observar que os dois grupos apresentaram um ganho constante, sendo o montante final acumulado pelo grupo ocitocina superior ao acumulado pelo grupo placebo (teste de Mann Whitney; $\mathrm{U}=286 \mathrm{p}<0,016$ ). 


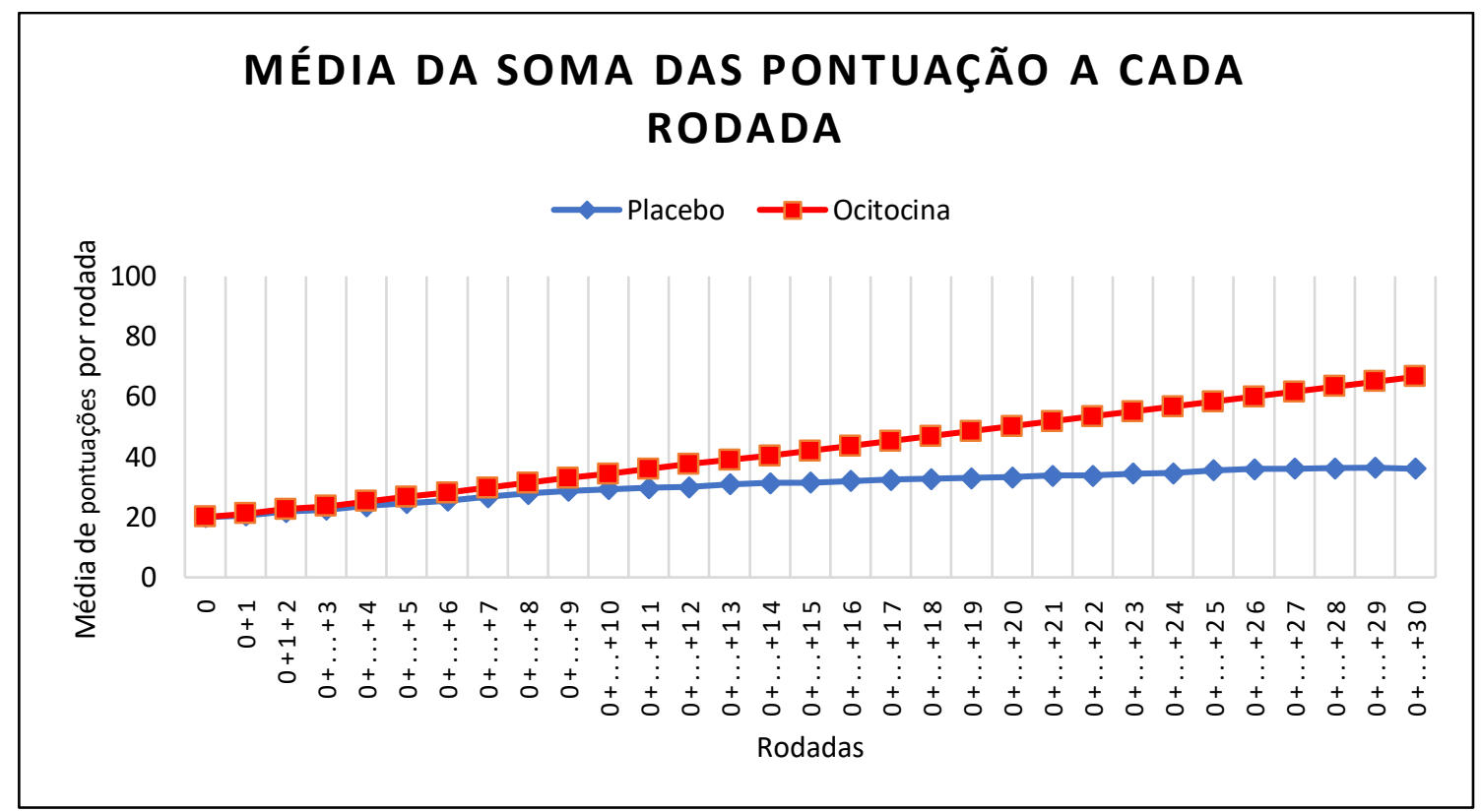

Figura 10: Soma acumulada de pontos (chocolate) por grupo por rodada ao longo das rodadas. A média do montante final do grupo de ocitocina (66,58 chocolates) foi diferente da média do montante final do grupo placebo $(36,13$ chocolates $) \mathrm{p}<0,016$.

A figura 11 representa a diferença entre as médias das pontuações em rodadas subsequentes para os grupos placebo e ocitocina, onde podemos identificar o ponto de equilíbrio (estabilização) nas cooperações. Para tal, utilizamos das médias de ganho ou perda em cada rodada e comparamos duas rodadas subsequentes. A comparação foi realizada subtraindo de cada rodada, a rodada anterior. Assim, iniciamos a comparação entre a segunda e a primeira rodada e finalizamos na trigésima comparando com a vigésima nona rodada), de forma que quando os valores não se alteram, temos a estabilização do comportamento de cooperação. Essa estabilização pôde ser notada para o grupo ocitocina antes da trigésima rodada. 
Estabilização do comportamento cooperativo

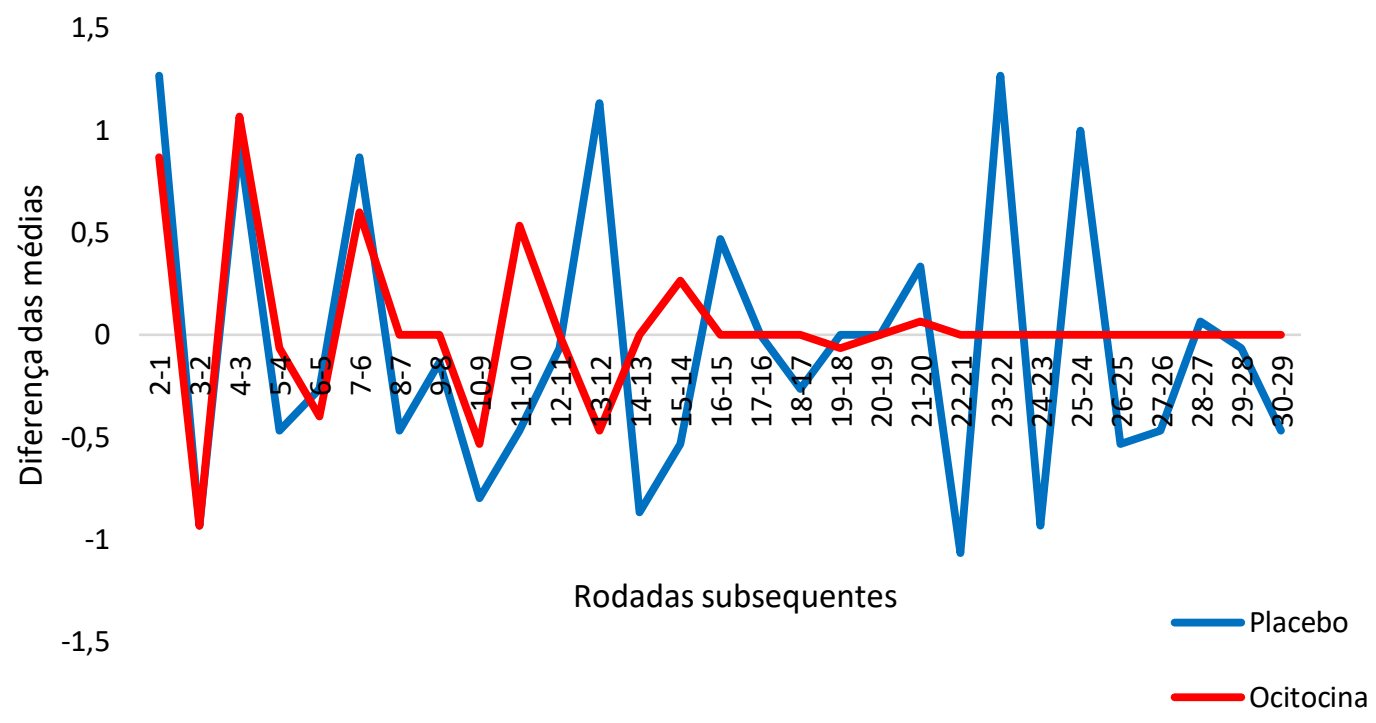

Figura 11:Diferença entre as médias das pontuações em rodadas subsequentes para os grupos placebo e ocitocina. 


\section{Discussão}

O presente estudo teve como objetivo principal investigar se a ocitocina intranasal altera o comportamento cooperativo ao longo do jogo dilema do prisioneiro iterado. De maneira geral, nossos resultados mostraram que: (1) o número total de cooperações foi maior para o grupo ocitocina; (2) o número de cooperações mútuas e, consequentemente, de pontuações foram maiores para o grupo ocitocina; (3) o grupo ocitocina apresentou ponto de estabilização do comportamento de cooperação; (4) o estado de humor dos voluntários não foi alterado após os procedimentos experimentais para nenhuma das categorias analisadas (tensão, raiva, vigor, confusão, fadiga e depressão).

Neste trabalho, a intenção de verificar o humor dos voluntários no início e no final do jogo foi saber se houve alguma interferência do processo experimental em seus estados de humores, que pudesse interferir no comportamento de cooperação Os resultados apresentados mostraram que não existe diferença entre as seis escalas propostas, assim podemos concluir que o processo experimental (aplicação da ocitocina ou placebo, tempo de espera, realização de atividades lúdicas, jogo e questionários) não causaram interferência no humor dos voluntários de ambos os grupos. Além disso, as comparações entre grupos também não mostraram diferenças no estado de humor dos voluntários. Dessa forma, podemos concluir que o uso da ocitocina não acarretou alterações de humor que pudessem caracterizar-se como preditores do comportamento de cooperação. Embora algumas alterações de humor já tenham sido relacionadas com a ação da ocitocina no sistema nervoso central (Niwayama, et al., 2017), acreditamos que o teste de humor de POMS seja um instrumento apropriado para avaliação dos perfis do humor com uma aplicação rápida, de fácil coleta e fácil análise de dados para ambientes de pesquisa (Nezu, et al., 1989; Ribeiro, et al., 2007).

Para compreendermos os resultados referentes ao comportamento de cooperação, é importante considerarmos que o problema da tomada de decisão é desafiador, pois os resultados de ações futuras raramente são previsíveis. Portanto, quando pessoas são colocadas para tomar decisões devemos levar em consideração a incerteza de suas escolhas (Kahneman \& Tversky, 1979). Muitas de nossas decisões mais importantes são tomadas no contexto de interações sociais, por exemplo, se 
quisermos decidir quão confiável uma pessoa é, precisamos integrar informações como expressões faciais, gestos, tom de voz, ações e linguagem (discurso figurativo, sarcasmo, ironia entre outros). Assim, com base na compreensão dos estados mentais de outras pessoas, fazemos previsões sobre o comportamento delas e ajustamos nossos próprios comportamentos, utilizando a capacidade de julgar comportamentos sobre como compreendemos as normas morais (Loewenstein, et al., 1989; O'Fallon \& Butterfield, 2005).

A potencial modulação do comportamento de tomada de decisão social pela ocitocina está relacionada à rede neural responsiva a esse neupeptídeo, centralizada na amígdala e altamente integrada, recebendo projeções de várias áreas corticais e subcorticais (Sanfey, 2003; Koenigs \& Tranel, 2007; Baumgartner 2011). No cenário dos jogos, as atividades neuronais desencadeadas pela ocitocina dependerão, em parte, das informações relacionadas à identidade social detectada por meio do jogo proposto, bem como daquelas relacionadas a possíveis conflitos emocionais, como o julgamento das decisões futuras. A ocitocina orienta o comportamento em direção a uma abordagem social específica após um contexto social. Portanto, a ocitocina ajusta o comportamento social de acordo com as demandas ambientais (Guastella, et al., 2009).

A relação ação - resposta (i. e. a próxima interação) pode mudar com frequência, dessa forma exige-se estratégias na tomada de decisão que dependem dos resultados observados nas interações anteriores (Sutton \& Barto, 2018). Posto isto, modelamos algumas situações de ação - resposta que poderiam ocorrer em nosso experimento (figura 12). A simulação I mostra como seria o comportamento com cooperação desde o início, não apresentando nenhuma traição entre os participantes (esta simulação foi encontrada em 4 casos sendo 3 no grupo com ocitocina e um no grupo placebo). Já a simulação II acontece o exato oposto do que foi proposto na situação I, ou seja, a cooperação não ocorre em nenhum momento e, dado à esta característica, o jogo teria fim na décima rodada com ambos os jogadores chegando a zero (nenhum grupo entre os dois tratamentos chegou a esse resultado). A simulação III apresenta outro exemplo extremo, onde um participante terá sempre o comportamento de cooperar, enquanto o outro nunca coopera, levando ao encerramento do jogo na rodada 20 com o participante que não cooperou ganhando 50 pontos como recompensa. A simulação IV foi realizada de forma que os participantes tivessem cooperado alternadamente de forma sequencial (i. e. um participante coopera na primeira rodada e não coopera na segundam enquanto 
o outro faz o contrário). A simulação $\mathrm{V}$ foi feita considerando comportamentos de cooperação aleatórios entre os voluntários, o que pode levar o jogo para qualquer configuração. $\mathrm{O}$ resultado apresentando na figura 12 foi composto de 20 simulações realizadas no Excel com a função "aleatórioentre" para cada rodada, considerando os valores propostos no experimento. Após as simulações serem compostas, foram feitas as médias dos valores para cada uma das rodadas a fim de exemplificar este dado.

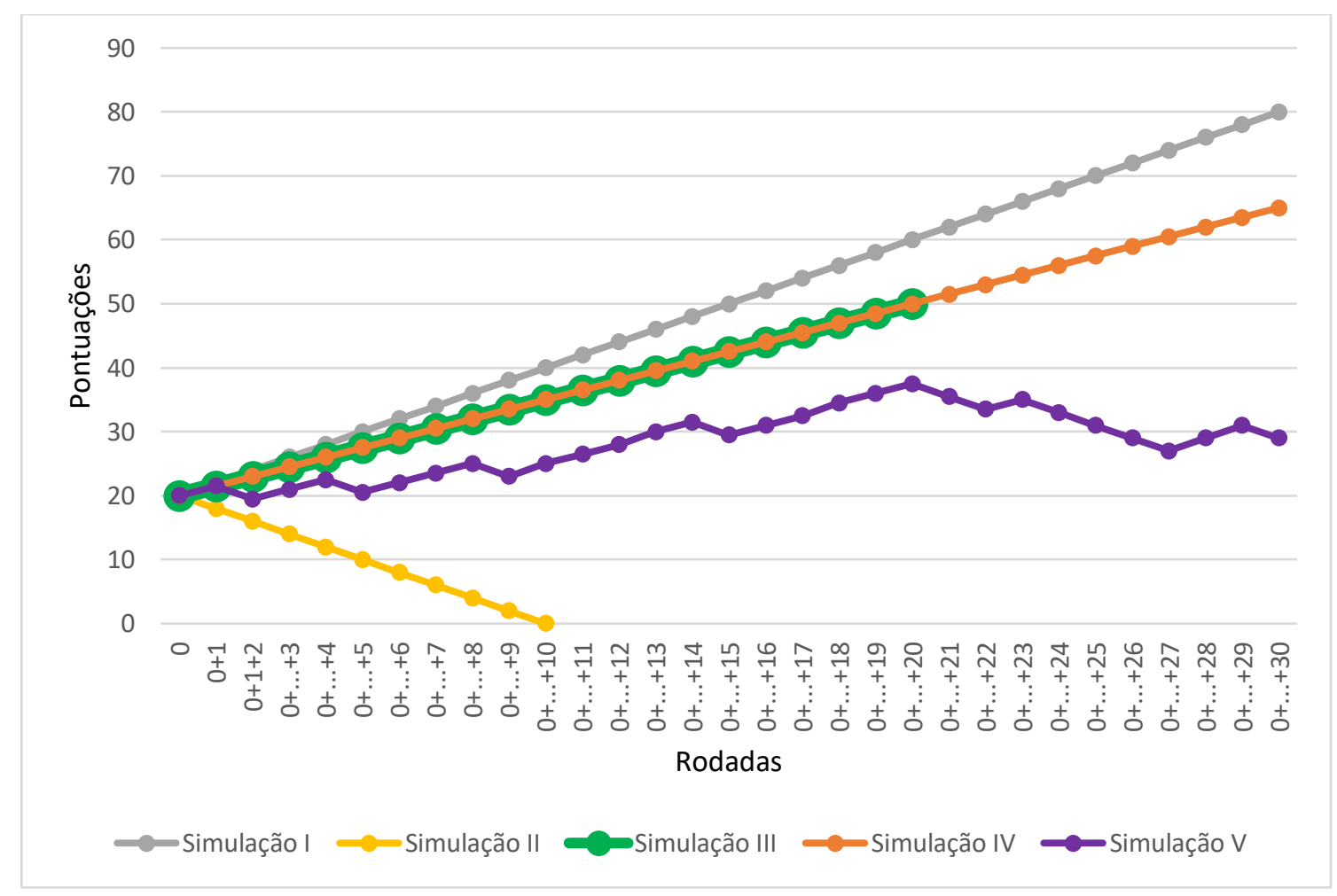

Figura 12: Soma acumulada de pontos em simulação de estratégias para o jogo dilema do prisioneiro iterado em 30 rodadas.

Estabelecendo um paralelo entre as simulações aqui propostas e os resultados referentes às médias da pontuação total de cada jogador, em cada rodada (figura 10), podemos observar que a curva do grupo ocitocina (valor final de 66,58 pontos) se assemelha tanto em inclinação, quanto em pontuação final com a curva obtida na simulação IV (valor final de 60,5 pontos). Ainda, o comportamento do grupo ocitocina apresenta características da situação I, pois nas primeiras rodadas do jogo os voluntários parecem passar por um período de experimentação das jogadas, testando o comportamento do jogador adversário. Assim, a estabilização das cooperações no grupo ocitocina acontece após a 14 rodada (figura 11). Desde a década de 1980 já temos uma 
ideia das melhores ou piores estratégias a serem escolhidas no dilema do prisioneiro iterado. Seguir o passo anterior de seu companheiro é tido como uma das melhores estratégias para apresentar o maior ganho possível, sem ser injustiçado (Axelrod, 1984). Esta também é considerada uma estratégia chave com relação à estabilização da cooperação (Axelrod \& Hamilton, 1981). Ao vermos que os resultados do grupo ocitocina se aproximam desses resultados simulados, podemos inferir que seus jogadores apresentam maior confiança entre si, resultando em mais cooperação. Além disso, as simulações realizadas com bases em estratégias teóricas sobre o dilema do prisioneiro iterado mostram a adequação de nosso modelo experimental e do software desenvolvido para os objetivos de nosso trabalho.

Os estudos neurobiológicos sobre tomada de decisão se concentraram nos mecanismos cerebrais mediadores do efeito da incerteza entre cooperar ou não cooperar, melhorando a estratégia na tomada de decisão (Schultz, 1997; Brieter, et al., 2001). Esses mecanismos envolvem estruturas relacionadas à estratégias que buscam a recompensa social como o estriado ventral, a área tegumentar ventral e as vias mesolímbicas, ativadas logo após o recebimento de uma recompensa (Rilling, et al., 2002; Sanfey, 2006; Sanfey, et al., 2007), bem como estruturas envolvidas no comportamento de cooperação - competição como o córtex pré-frontal, córtex orbitofrontal, córtex cingulado anterior, amigdala e insula (Rilling, et al., 2002; Sanfey, et al., 2007). Estes estudos sobre tomada de decisão vêm examinando o comportamento cooperativo em simulações de jogos sobre as escolhas feitas durante o dia a dia.

Em nosso estudo, os participantes com ocitocina apresentaram um número alto de cooperações (figura 7) que se distribuíram ao longo das interações de todo o jogo (figura 8), com percentuais maiores nos dois terços finais do jogo. Isso parece indicar que a ocitocina contribuiu para aumentar o comportamento de cooperação no cenário do jogo. Esses dados corroboram as pesquisas apresentadas por Rilling (2002 e 2008), Kirsch (2005), Sanfey (2006), Zak (2007), mostrando que as decisões de confiar nos outros são aprimoradas pela ocitocina, atenuando o medo de que a não cooperação ocorra, uma vez que suprime a atividade da amígdala e da insula anterior. A redução da ativação da amígdala pela ocitocina, aumenta a capacidade parassimpática e inibe os neurônios responsáveis pela liberação de corticosteroides, resultando na diminuição do comportamento de medo (Domes et al., 2007; Neumann, 2008). 
Além disso, devemos considerar a importância do córtex pré-frontal neste cenário. Sanfey e colaboradores (2003) descobriram que a percepção de comportamentos injustos provoca ativação de regiões envolvidas no processamento da cognição (córtex pré-frontal dorsolateral) e da emoção (ínsula anterior e da amigdala). Essas áreas mostraram-se mais ativadas quando voluntários recebem uma oferta injusta e subsequentemente não as aceitam, podendo despertar um comportamento punitivo como o de não cooperar nas próximas interações. Esse resultado pode explicar o comportamento do grupo placebo, pois como a cooperação não foi realizada de forma mútua, os jogadores demoram para adquirir confiança no seu adversário, punindo-os nas jogadas subsequentes, mesmo que essas punições correspondessem a uma perda pessoal (não maximizar seu próprio ganho).

Também foi observado uma maior resposta no córtex pré-frontal dorsolateral quando uma oferta injusta foi aceita. A ativação da região da ínsula anterior está envolvida na excitação emocional e relacionadas às taxas de rejeição de ofertas injustas (Rilling, et al., 2002; Sanfey, et al., 2007; Neumann, 2008). Já a ativação do córtex préfrontal ventromedial ocorre frente a ofertas justas, contrapondo-se à situação de uma oferta injusta. Também foi mostrado que existe uma correlação entre o córtex préfrontal ventromedial e a ofertas justas, pois ao analisar pacientes com lesão cerebral no córtex pré-frontal ventromedial, as ofertas injustas são rejeitadas com maior frequência quando comparada a pessoas saudáveis (Koenigs \& Tranel, 2007).

Para distinguir as funções de diferentes áreas do cérebro na tomada de decisão relacionada à justiça social, Knoch e colaboradores (2006) usaram a estimulação magnética transcraniana repetitiva para inibir a ativação do córtex pré-frontal dorsolateral direito, quando os sujeitos enfrentaram uma situação de injustiça em jogo. Foi observado que as ofertas injustas eram aceitas com maior frequência, sugerindo que os participantes foram mais incapazes de recusar ofertas injustas. No geral, as pessoas tem preferências em reduzir a desigualdade, sendo que quando a desigualdade e a eficiência (resultado do jogo) entram em conflito, os participantes demonstravam maior atividade nas regiões pré-frontais descritas acima (Baumgartner, et al., 2011; Fehr \& Schmidt, 1999).

As interações sociais com resultados desiguais estão ligadas a sistemas neurais que incluem a ínsula anterior, amígdala e o córtex pré-frontal, associados à sinalização cognitivas, afetivas e emocionais que alteram as decisões de distribuição, modulando as 
percepções de justiça. Ademais, a desigualdade pode induzir uma ação punitiva como por exemplo o fim da cooperação. Assim, as redes neurais implicadas na aversão à iniquidade podem levar à decisão de punir mesmo apresentando um alto custo ao punidor. Além disso, evidências convergentes sugerem que tarefas de decisão relacionadas à injustiça normalmente ativam regiões cerebrais envolvidas no processamento afetivo.

Vale ressaltar que receptores de ocitocina são encontrados em diversas regiões de nosso sistema nervoso central, dentre as quais podemos destacar aquelas que estão presentes no comportamento cooperativo e na tomada de decisão (córtex pré-frontal, córtex e cingulado anterior) (Boccia, et al., 2013; Mitre, et al., 2016). Entretanto, a compreensão da ação moduladora da ocitocina sobre a circuitaria dessas estruturas frente à cenários de julgamento social ainda é pequena. Nossos achados referentes à estabilização do comportamento de cooperação para o grupo ocitocina podem estar relacionados com seu possível efeito nessas estruturas, uma vez que ao analisar o comportamento de cooperação ou não cooperação do adversário, o jogador sob efeito da ocitocina desenvolve julgamentos que interferem na tomada de decisão no sentido de aumentar a probabilidade de cooperação. Isso gera um círculo virtuoso para o comportamento de cooperação de ambos os jogadores, demonstrado pelo aumento de cooperações mútuas encontrado para o grupo ocitocina (Figura 9).

Um último ponto a se destacar está relacionado às bases neurais do comportamento cooperativo e o sistema de recompensa. Em estudos realizados por Rilling e colaboradores (2002 e 2004) foram demostrados que participantes envolvidos em jogo do dilema do prisioneiro iterado apresentavam maior ativação do estriado ventral, quando interagia com outro ser humano. $\mathrm{O}$ mesmo não acontecia quando a interação foi com um programa de computador. Durante o jogo com humanos foi identificado que a rede neural de recompensa era mais ativa se a cooperação fosse mútua, entretanto, ao não ocorrer cooperação os resultados tinham uma menor ativação desta área. Quando a ação de cooperar se dava unilateralmente, existia a ativação da amígdala e ínsula anterior como uma forma de antecipação da norma de reciprocidade (Rilling et al., 2008).

O envolvimento do estriado em processos de recompensa parece variar, dependendo se a interpretação dos resultados foi considerada competição ou cooperação (Fliessbach, et al., 2007). Da mesma forma, quando os participantes jogaram de forma 
competitiva ou cooperativa, regiões diferentes do cérebro foram ativadas em dois padrões distintos de interação (Babiloni, et al., 2007). No entanto, atualmente não se sabe como essas regiões corticais estão ligadas à atividade estratégica envolvida na cooperação, mas é possível destacar áreas que influenciam tanto no sistema de recompensa quanto na tomada de decisão, como o córtex orbitofrontal (Rilling, 2004).

Trabalhos anteriores usando ferramentas de imagem como a ressonância magnética funcional permitiram a identificação das redes neurais envolvidas no comportamento cooperativo. No entanto, essas ferramentas podem fornecer apenas suporte limitado a esse objetivo ambicioso, pois não possuem resolução temporal. Além disso, eles não permitem um ambiente on-line de troca social na vida real, sendo que a interação social é parte essencial do comportamento cooperativo.

A ocitocina tem sido implicada como mediadora de comportamentos e atividades socialmente gratificantes por meio de sua modulação sobre os sistemas mesolímbicos (Kovács, et al. 1988; Sarnyai, et al., 2014), o que vai de encontro com a presença de projeções ocitocinérgicas dos núcleos hipotalâmicos paraventricular e supraóptico para a área tegmental ventral e núcleo accumbens, onde há receptores de ocitocina (Boccia, et al., 2013; Mitre et al., 2016). O conjunto dos achados aqui mensionados nos orienta para novamente estabelecer uma relação entre o efeito da ocitocina nasal no sistema nervoso central e o comportamento de cooperação do grupo ocitocina, principalmente quando consideramos as consequências reforçadoras da cooperação mútua no jogo aqui proposto. Assim, a modulação ocitocinérgica sobre a via mesolímbica contribui para a estabilização do comportamento de cooperação dentro do círculo virtuoso estabelecido.

De maneira geral, a ação da ocitocina sobre comportamentos de cooperação parece ser possível por meio da modulação de diversos circuitos envolvidos na tomada de decisão. 


\section{Conclusão}

Este estudo mostrou a modulação da ocitocina sobre o comportamento cooperativo, uma vez que os voluntários tratados com ocitocina apresentaram maiores pontuações no jogo dilema do prisioneiro. Embora não seja possível evidenciar em qual(is) área(s) envolvidas na tomada de decisão houve a interferência da ocitocina, podemos pontuar as circuitarias envolvidas com o processamento da recompensa social e confiança como alvos potenciais da modulação ocitocinérgicas no cenário de jogo.

Ainda, o estado de humor dos voluntários sob o efeito da ocitocina não pôde ser considerado como um preditor do comportamento de cooperação, uma vez que não houve alterações significativas nas comparações intragrupos e intergrupos.

Por fim, o software desenvolvido se mostrou adequado para a aplicação do jogo sequencial inspirado no dilema do prisioneiro iterado.

A ocitocina é um importante neuro-hormônio envolvido em diversos processos biopsicossociais. Muitos mecanismos de ação ainda precisam ser desvendados e melhor esclarecidos por meio de estudos futuros, o que renderá importantes conhecimentos a respeito da fisiologia e neuromodulação de diversos fenômenos em seres humanos. 


\section{Referências Consultadas}

Adolphs, R., Tranel, D., Damasio, H., Damasio, A. (1994). Impaired recognition of emotion in facial expressions following bilateral damage to the human amygdala. Nature. 15;372(6507):669-72.

Adolphs, R., Tranel, D., Damasio, A. R. (1998). The human amygdala in social judgment, Nature. 1998 Jun 4;393(6684):470-4.r.

Anton, F. \& Peppel, P. (1991). Central projections of trigeminal primary afferents innervating the nasal mucosa: a horseradish peroxidase study in the rat. Neuroscience. 41(23):617-28.

Axelrod, R. \& Hamilton, W. D. (1981). The Evolution of Cooperation. Science, New Series. Vol. 211, No. 4489, pp. 1390-1396.

Axelrod, R. (1984). The Evolution of Cooperation. Basic Books, Inc. New York. https://doi.org/10.1017/CBO9781107415324.004.

Babiloni, F., Astolfi, L., Cincotti, F., Mattia, D., Tocci, A., Tarantino, A., et al. (2007). "Engineering in medicine and biology society, EMBS 2007," Proceedings of the 29th Annual International Conference of the IEEE Paris: 4953-4956.

Bahadur, S., \& Pathak, K. (2012). Physicochemical and physiological considerations for efficient nose-to-brain targeting. Expert Opin Drug Deliv. 9(1), 19-31. https://doi.org/10.1517/17425247.2012.636801.

Barraclough, D. J., Conroy, M. L., Lee, D. (2004). Prefrontal cortex and decision making in a mixed-strategy game. Nat Neurosci 7(4):404-10.

Baumgartner, T., Knoch, D., Hotz, P., Eisenegger, C., Fehr, E. (2011). Dorsolateral and ventromedial prefrontal cortex orchestrate normative choice. Nat. Neurosci. 14 1468-1474. 10.1038/nn.2933.

Boccia, M. L. Petrusz, P., Suzuki, K., Marson, L., Pedersen, C. A. (2013). Immunohistochemical localization of oxytocin receptors in human brain. Neuroscience. 3; 253:155-64. doi: 10.1016/j.neuroscience.2013.08.048.

Bowles, S. \& Gintis, H. (2003). The Origins of Human Cooperation. In book: Genetic and Cultural Origins of Cooperation, Publisher: MIT Press, Editors: Peter Hammerstein.

Brieter, H. C., Aharon, I. Kahneman, D., dale, A., Shizgal, P. (2001). Functional imaging of neural responses to expectancy and experience of monetary gains and losses. Neuron. 30(2):619-39.

Cacioppo, J. T., (1994) Social neuroscience: autonomic, neuroendocrine, and immune responses to stress. Psychophysiology. 31(2):113-28.

Campbell, A. (2010). Oxytocin and human social behavior. Personality and Social Psychology Review. 14(3), 281-295. https://doi.org/10.1177/1088868310363594.

Carvalho, T. M. (1957). A Teoria dos Jogos e sua Aplicação á Economia. Revista Brasileira de economia.

Chang, H. H., \& Tuan Pham, M. (2013). Affect as a Decision-Making System of the Present. Journal of Consumer Research. 40(1), 42-63. https://doi.org/10.1086/668644.

Charnov, E. L. (1976). Optimal foraging theory: the marginal value theorem. Theoretical Population Biology. 9, 129-136. https://doi.org/10.1016/0040-5809(76)90040-X.

Chen, Y. (2011). Microeconomic Theory: Basics of Noncooperative Games. Retrieved from http://spot.colorado.edu/ cheny/course/phdmicro/topic2.pdf. 
Cruz, J. F., \& Viana, M. F. (1993). Competências psicológicas dos atletas de elite (Relatório Técnico). Braga-Lisboa: Projecto de Investigação e Intervenção Psicológica na Alta Competição.

Dai, Y. \& Lu, Peng. (2015). When does inferring reputation probability countervail temptation in cooperative behaviors for the prisioners' dilemma game? Chaos, Solitons \& Fractals. 78, 238-244.

Dalley, J. W., Cardinal, R. N., Robbins, T. W. (2004). Prefrontal executive and cognitive functions in rodents: neural and neurochemical substrates, Neurosci Biobehav Rev. 28(7):771-84.

Damasio, A.R., (1995). On some functions of the human prefrontal cortex. Ann N $Y$ Acad Sci. 769:241-51.

de Paula Le Sueur, L., Kalapothakis, E., da Cruz-Höfling, M. A. (2003). Breakdown of the blood-brain barrier and neuropathological changes induced by Phoneutria nigriventer spider venom. Acta Neuropathologica. 105(2), 125-134. https://doi.org/10.1007/s00401-002-0623-8.

Domes, G., Heinrichs, M., Michel, A., Berger, C., \& Herpertz, S. C. (2007). Oxytocin Improves "Mind-Reading" in Humans. Biological Psychiatry. 61(6), 731-733. https://doi.org/10.1016/j.biopsych.2006.07.015.

Donaldson, Z., R., \& Young, L. J. (2008). Oxytocin, Vasopressin and the neurogenics of sociality. Science. 322(November 2008), 900-905. https://doi.org/10.1126/science.1158668.

Dutta, P.K. (1999). Strategies and Games: Theory and Practice. Cambridge, MA: MIT Press, pp. 423-459.

Fehr, E., Camerer, C. F. (2007). Social neuroeconomics: the neural circuitry of social preferences. Trends Cogn. Sci. 11(10):419-27.

Fehr, E. \& Schmidt, K. M. (1999). A theory of fairness, competition, and cooperation. Q. J. Econ. 114 817-868. 10.1098/rspb.2015.0392.

Fliessbach, K., Weber, B., Trautner, P., Dohmen, T., Sunde, U., Elger, C. E., et al. (2007). Social comparison affects reward-related brain activity in the human ventral striatum. Science. 318 1305-1308. 10.1126/science.1145876.

Figueiredo, R. S. (1972). Matemática E Aplicação À Distribuição De Custo. Revista Brasileira de economia.

Frank, R. H., (1988). Passions Within Reason: The Strategic Role of the Emotions. New York: Norton. $304 \mathrm{pp}$

Frith, C. D., Singer, T. (2008). The role of social cognition in decision making. Philos. Trans. R. Soc. Lond. B Biol.Sci. 363:3875-86.

Gammie, S. C. (2010). Effects of Stress on General Social Behaviors. Stress and Social Behavior. 334-341. https://doi.org/http://dx.doi.org/10.1016/B978-0-08-045396-5.00237-2.

Garcia, A. \& Otta, E. (2002). Konrad Lorenz's Work: a Conceptual Framework and a Bibliography. Revista de Etologia, 4 (1), 49-66.

Garcia, A. (2005). Cognição e evolução: a contribuição de Konrad Lorenz. Ciências \& Cognição, 4, 89-100.

Gazzaniga, M.S. (1985). The Social Brain. New York, Basic Books.

Gimpl, G., \& Fahrenholz, F. (2001). The Oxytocin Receptor System : Structure , Function, and Regulation. Regulation. 81(2), 629-683. $1-169$.

Griffin, C. (2012). Game Theory: Penn State Math 486 Lecture Notes. Lecture Notes, 
Guastella, A. J., Howard, A. L., Dadds, M. R., Mitchell, P., Carson, D. S. (2009). A randomized controlled trial of intranasal oxytocin as an adjunct to exposure therapy for social anxiety disorder. Psychoneuroendocrinology. Vol. 34, pp. 917-923.

Guastella, A. J., Hickie, I. B., McGuinness, M. M., Otis, M., Woods, E. A., Disinger, H. M., Banati, R. B. (2013). Recommendations for the standardisation of oxytocin nasal administration and guidelines for its reporting in human research. Psychoneuroendocrinology. 38(5), 612-625. https://doi.org/10.1016/j.psyneuen.2012.11.019.

Hardin, G. J. (1968). The tragedy of the commons. doi.org/10.1056/NEJMopv0907258.

Hart, S. (1992). Chapter 2 Games in extensive and strategic forms. Handbook of Game Theory with Economic Applications 1, 19-40. https://doi.org/10.1016/S1574-0005(05)80005-0.

Heatherton, T. F., Niel-MacRae, C. Kelley, W. M. (2004). What the Social Brain Sciences Can Tell Us About the Self. Current Directions in Psychological Science. Vol 13, Issue 5, pp. 190 - 193.

Heinrichs, M., Baumgartner, T., Kirschbaum, C., Ehlert, U. (2003). Social support and oxytocin interact to suppress cortisol and subjective responses to psychosocial stress. Biological Psychiatry. 54(12), 1389-1398. https://doi.org/10.1016/S0006-3223(03)00465-7

Hirshleifer, J. \& Coll, J. C. M. (1988). What Strategies Can Support the Evolutionary Emergence of Cooperation? Journal of Conflict Resolution.

Irngartinger, M., Camuglia, V., Damm, M., Goede, J., Frijlink, H. W. (2004). Pulmonary delivery of therapeutic peptides via dry powder inhalation: Effects of micronisation and manufacturing. European Journal of Pharmaceutics and Biopharmaceutics. 58(1), 7-14. https://doi.org/10.1016/j.ejpb.2004.03.016.

Jahng, A. I., Wittig, J. H., Inati, K. S., Zaghloul, K. A. (2017). Human Cortical Neurons in the Anterior Temporal Lobe Reinstate Spiking Activity during Verbal Memory Retrieval. Current Biology.

Janak, P. H., Tye, K. M. (2015). From circuits to behaviour in the amygdala, Nature. 15;517(7534):284-92. doi: 10.1038/nature14188.

Jansson, B., \& Björk, E. (2002). Visualization of in vivo olfactory uptake and transfer using fluorescein dextran. Journal of Drug Targeting. 10(5), 379-386. https://doi.org/10.1080/1061186021000001823.

Jolkkonen, E., Miettinen, R., \& Pitkänen, A. (2001). Projections from the amygdalopiriform transition area to the amygdaloid complex: A PHA-L study in rat. Journal of Comparative Neurology. 432(4), 440-465. https://doi.org/10.1002/cne.1113.

Kahneman, D. \& Tversky, A. (1979). Prospect Theory: An Analysis of Decision under Risk. Econometrica, Vol. 47, No. 2, pp. 263-291.

Kang, N., Baum, M. J., \& Cherry, J. A. (2011). Different profiles of main and accessory olfactory bulb mitral/tufted cell projections revealed in mice using an anterograde tracer and a whole-mount, flattened cortex preparation. Chemical Senses. 36(3), 251-260. https://doi.org/10.1093/chemse/bjq120.

Kirsch, P. (2005). Oxytocin Modulates Neural Circuitry for Social Cognition and Fear in Humans. Journal of Neuroscience. 25(49), 11489-11493. https://doi.org/10.1523/JNEUROSCI.3984-05.2005.

Koenigs M., Tranel D. (2007). Irrational economic decision-making after ventromedial prefrontal damage: evidence from the Ultimatum Game. J. Neurosci. 27 951-956.

Kollock, P. (1998). Social Dilemmas: The Anatomy of Cooperation. Annual Review of Sociology. Vol. 24:183-214. https://doi.org/10.1146/annurev.soc.24.1.183. 
Kosfeld, M., Heinrichs, M., Zak, P. J., Fischbacher, U., \& Fehr, E. (2005). Oxytocin increases trust in humans. Nature. 435(7042), 673-676. https://doi.org/10.1038/nature03701.

Knoch, D., Pascual-Leone, A., Meyer, K., Treyer, V., Fehr, E. (2006). Diminishing reciprocal fairness by disrupting the right prefrontal cortex. Science. 314 829-832. 10.1126/science. 1129156 .

Lee, D. (2008). Game theory and neural basis of social decision making. Nat Neurosci. 11(4), 404-409. https://doi.org/10.1038/nn2065.

Lee, H. J., Macbeth, A. H., Pagani, J. H., Scott Young, W. (2009). Oxytocin: The great facilitator of life. Progress in Neurobiology. 88(2), 127-151.

https://doi.org/10.1016/j.pneurobio.2009.04.001.

Lim, M. M., \& Young, L. J. (2006). Neuropeptidergic regulation of affiliative behavior and social bonding in animals. Hormones and Behavior. 50(4), 506-517. https://doi.org/10.1016/j.yhbeh.2006.06.028.

Loewenstein, G. F., Thompson, L., \& Bazerman, M. H. (1989). Social utility and decision making in interpersonal contexts. Journal of Personality and Social Psychology. 57(3), 426-441. https://doi.org/10.1037/0022-3514.57.3.426.

Maynard-Smith, J. (1982). Evolution and the Theory of Games. Book, Cambridge University Press.

McCarthy, M. M., McDonald, C. H., Brooks, P. J., \& Goldman, D. (1996). An anxiolytic action of oxytocin is enhanced by estrogen in the mouse. Physiology and Behavior, 60(5), 1209-1215. https://doi.org/10.1016/S0031-9384(96)00212-0

McNamara, J. M., Barta, Z., Houston, A. I. (2004) Variation in behaviour promotes cooperatio in Prisoner's Dilemma game. Nature. 428, 745-748.

Meddle, S. L., Leng, G., Selvarajah, J. R., Bicknell, R. J., Russell, J. A. (2000). Direct pathways to the supraoptic nucleus from the brainstem and the main olfactory bulb are activated at parturition in the rat. Neuroscience. 101(4), 1013-1021. https://doi.org/10.1016/S03064522(00)00300-6.

Milléo Filho, G., Rubens, R., Sérgio, P. (2004). Um modelo Baseado no Paradigma do Dilema do Prisioneiro Iterado para Simulação de Competição Empresarial. IV Congresso Brasileiro de Computação, 402-406.

Mitre, M., Marlin, B. J., Schiavo, J. K., Morina, E., Norden, S. E., Hackett, T. A., Aoki, C. J., Chao, M. V., Froemke, R. C. (2016). A Distributed Network for Social Cognition Enriched for Oxytocin Receptors. J Neurosci. 36(8):2517-35. doi: 10.1523/JNEUROSCI.240915.2016 .

Neumann, I. D. (2008). Brain oxytocin: A key regulator of emotional and social behaviours in both females and males. Journal of Neuroendocrinology. 20(6), 858-865. https://doi.org/10.1111/j.1365-2826.2008.01726.x.

Nezu, A. M., Nezu, C. M., \& Blissett, S. E. (1988). Sense of humor as a moderator of the relation between stressful events and psychological distress: A prospective analysis. Journal of Personality and Social Psychology. 54(3), 520-525. doi:10.1037/0022-3514.54.3.520

Niwayama, R., Nishitani, S., Takamura, T., Shinohara, K., Honda, S., Miyamura, T., Nakao, Y., Araki-Nagahashi, M. (2017). Oxytocin Mediates a Calming Effect on Postpartum Mood in Primiparous Mothers. Breastfeeding Medicine. Vol. 12, No. 2

Nöe, R. (2006). Cooperation experiments: coordination through communication versus acting apart together. Animal Behaviour. Vol 71, pp 1-18.

Nowak, M. A. (2012). Five rules for the evolution of cooperation, Science. 314(5805): 1560-1563.doi: 10.1126/science. 1133755 
Oliveira, F. A. \& Araújo, M. A. (2010). O Teorema Minimax de Von Neumann. Anais do Congresso Nacional de matemática aplicada e computacional.

Osborne, M. J. (2000). An Introduction to Game Theory. Book, 1-685. https://doi.org/10.1192/pb.26.12.476-a.

Ostrom, E. (1999). Coping with tragedies of the commons. Annual Review of Political Science. Vol. 2:493-535. https://doi.org/10.1146/annurev.polisci.2.1.493.

O'Fallon, M. J. \& Butterfield, K. D. (2005). A Review of The Empirical Ethical Decision-Making Literature: 1996-2003. Journal of Business Ethics. volume 59, pages375-413.

Petrovic, P., Kalisch, R., Singer, T., \& Dolan, R. J. (2008). Oxytocin Attenuates Affective Evaluations of Conditioned Faces and Amygdala Activity. Journal of Neuroscience. 28(26), 6607-6615. https://doi.org/10.1523/JNEUROSCI.4572-07.2008.

Quervain, D. J. De, Fischbacher, U., Treyer, V., \& Schellhammer, M. (2004). The Neural Basis of Altruistic Punishment Supporting Online Material. Science, 305(5688), 1254 1258. https://doi.org/10.1126/science.1100735.

Quintana, D. S., Alvares, G. A., Hickie, I. B., Guastella, A. J. (2015). Do delivery routes of intranasally administered oxytocin account for observed effects on social cognition and behavior? A two-level model. Neuroscience and Biobehavioral Reviews. 49, 182-192. https://doi.org/10.1016/j.neubiorev.2014.12.011

Rand, D. G., Greene, J. D., Nowak, M. A. (2012). Spontaneous giving and calculated greed. Nature. 489(7416), 427-430. https://doi.org/10.1038/nature11467.

Rasmusen, E. (2006). Games and Information: an Introduction to Game Theory (4a ed). Hobo Ribeiro de Macedo, I. O., De Moura Simim, M. A., \& Noce, F. (2007). A UTILIZAÇAO DO POMS NO MONITORAMENTO DOS ESTADOS DE HUMOR ANTES DA COMPETIÇAO NAS DIFERENTES PROVAS DO ATLETISMO. Cuadernos De Psicología Del Deporte. 7(1), 85-96. Recuperado a partir de https://revistas.um.es/cpd/article/view/54681ken, NJ: Wiley-Blackwell.

Rilling, J. K., Gutman, D. A., Zeh, T. R., Pagnoni, G., Berns, G. S., \& Kilts, C. D. (2002). A neural basis for social cooperation. Neuron. 35(2), 395-405. https://doi.org/10.1016/S0896-6273(02)00755-9.

Rilling, J. K., Sanfey, A. G., Aronson, J. A., Nystrom, L. E., Cohen J. D. (2004). The neural correlates of theory of mind within interpersonal interactions. Neuroimage 221694 1703. 10.1016/j.neuroimage.2004.04.015.

Rilling, J. K., King-Casas, B., \& Sanfey, A. G. (2008). The neurobiology of social decision-making. Current Opinion in Neurobiology, 18(2), 159-165. https://doi.org/10.1016/j.conb.2008.06.003.

Rilling, J. K., Sanfey, A. G. (2011). The neuroscience of social decision-making. Annu Rev Psychol. 62:23-48. doi: 10.1146/annurev.psych.121208.131647.

Rose, N. \& Abi-Rache, J. M. (2013) Neuro: the new brain sciences and the management of the mind. Princeton: Princeton University Press.

Salamone, J. D., Correa, M., Yang, J. H., Rotolo, R., Presby, R. (2018). Dopamine, Effort-Based Choice, and Behavioral Economics: Basic and Translational Research, Front Behav Neurosci. 23;12:52. doi: 10.3389/fnbeh.2018.00052.

Sampaio, A. A. S. (2005). Skinner: sobre ciência e comportamento humano. Psicologia: Ciência e Profissão.

Sanfey, A. G., Rilling, J. K., Aronson, J; A., Nystrom, L.E., Cohen, J. D. (2003). The neural basis of economic decision-making in the Ultimatum Game. Science. 13:300 (5626): $1755-8$. 
Sanfey, A.G., Loewenstein, G., McClure, S.M., Cohen J.D. (2006). Neuroeconomics: cross-currents in research on decision-making. Trends Cogn. Sci. 10:108-16

Sanfey, A. G. (2007). Social decision-making: insights from game theory and neuroscience. Science, 318 (5850): 598-602.

Sartini, B. A., Garbugio, G., Bortolossi, H. J., Santos, P. A., Barreto, L. S. (2004). Uma introdução a teoria dos jogos. II Bienal Da SBM - Universidade Federal Da Bahia. Retrieved from http://www.uspleste.usp.br/rvicente/IntroTeoriaDosJogos.pdf.

Schultz, W., Dayan, P., Montague, P.R. (1997). A neural substrate of prediction and reward. Science. 275(5306):1593-9.

Sejwal, R. (2014). Game Theory and Human Behavior. International Research Journal of Management Sociology \& Humanity. 5(3), 361-365.

Singer, T., Snozzi, R., Bird, G., Petrovic, P., Silani, G., Heinrichs, M., Dolan, R. J. (2008). Effects of Oxytocin and Prosocial Behavior on Brain Responses to Direct and Vicariously Experienced Pain. Emotion. 8(6), 781-791. https://doi.org/10.1037/a0014195.

Souza, D. G. (2001). O Que É Contingência? In Banaco, R. A. (org) - Sobre Comportamento e Cognição - aspectos teóricos, metodológicos e de formação em Análise do Comportamento e Terapia Cognitivista. Santo André, SP: ESETec Editores Associados, 2001.

Stoop, R. (2012). Neuromodulation by Oxytocin and Vasopressin. Neuron. 76(1), 142159. https://doi.org/10.1016/j.neuron.2012.09.025.

Striepens, N., Kendrick, K. M., Hanking, V., Landgraf, R., Wüllner, U., Maier, W., \& Hurlemann, R. (2013). Elevated cerebrospinal fluid and blood concentrations of oxytocin following its intranasal administration in humans. Scientific Reports. 3, 1-5. https://doi.org/10.1038/srep03440.

Sutton, R. S., \& Barto, A. G. (2018). Reinforcement learning: An Introduction, 2nd edition. Book, MIT press.

Thorne, R. G., Pronk, G. J., Padmanabhan, V., Frey, W. H. (2004). Delivery of insulinlike growth factor-I to the rat brain and spinal cord along olfactory and trigeminal pathways following intranasal administration. Neuroscience. Vol. 127, pp 481 - 496.

Viana, M. F., Almeida, P., \& Santos, R. C. (2012). Adaptação portuguesa da versão reduzida do Perfil de Estados de Humor - POMS. Análise Psicológica, 19(1), 77-92. https://doi.org/10.14417/ap.345.

Vicent, T. L. \& Brown, J. S. (1988) The evolution of ESS theory. Annual Review of Ecology and Systematics. 19: 423-443, http://dx.doi.org/10.1146/annurev.es.19.110188.002231.

Viero, C., Shibuya, I., Kitamura, N., Verkhratsky, A., Fujihara, H., Katoh, A., Dayanithi, G. (2010). Oxytocin: Crossing the bridge between basic science and pharmacotherapy. CNS Neuroscience and Therapeutics. 16(5), 138-156. https://doi.org/10.1111/j.1755-5949.2010.00185.x

Wang, Y. L., Yuan, Y., Yang, J., Wang, C. H., Pan, Y. J., Lu, L., Liu, W. Y. (2013). The interaction between the oxytocin and pain modulation in headache patients. Neuropeptides, 47(2), 93-97. https://doi.org/10.1016/j.npep.2012.12.003.

Wolburg, H., Wolburg-Buchholz, K., Sam, H., Horvát, S., Deli, M. A., Mack, A. F. (2008). Epithelial and endothelial barriers in the olfactory region of the nasal cavity of the rat. Histochemistry and Cell Biology, 130(1), 127-140. https://doi.org/10.1007/s00418-008-0410-2.

Viviani, D., Charlet, A., Van Den Burg, E., Robinet, C., Hurni, N., Abatis, M., Stoop, R. (2011). Oxytocin selectively gates fear responses through distinct outputs from the central amygdala. Science. 333(6038), 104-107. https://doi.org/10.1126/science.1201043. 
von Neumann, J., \& Moigenstem, O. (1944). The Theory of Games and Economic Behavior. Princeton, NJ: Princeton University Press.

Zak, P. J., Stanton, A. A., Ahmadi, S. (2007). Oxytocin Increases Generosity in Humans, (11), 1-5. https://doi.org/10.1371/journal.pone.0001128. 


\section{Anexos}

\section{Anexo 1}

Questionário 1

Nome:

Idade: Telefone: ( ) E-mail:

Curso de graduação:

Você possui algum problema de saúde? ( ) Sim ( ) Não

Se sim, qual?

Você possui alguma doença, ou faz algum acompanhamento neurológico ou psiquiátrico? ( ) Sim ( ) Não

Se sim, qual?

Faz uso de rotina de algum medicamento? ( ) Sim ( ) Não

Se sim, qual?

Fuma? ( ) Sim ( ) Não Se sim, quantos cigarros por dia?

Faz uso de álcool? ( ) raramente ( ) em poucas ocasiões ( ) todos finais de semana ( ) todos os dias

Faz uso de algum tipo de droga ilícita? ( ) Sim ( ) Não

Se sim, qual droga? com qual frequência?

Você evita alguns alimentos por motivos de saúde? ( ) Sim ( ) Não

Se sim, qual?

Você pratica esportes?

( ) Sim ( ) Não

Se sim, qual frequência?

Quantas vezes você come ao dia?

( ) $1 \mathrm{x}$ ( ) 2x ( ) 3x ( ) 4x ( ) 5x ( ) Mais

Quantas horas de sono em média você dorme por dia?

( ) Menos de 4 horas ( ) De 4 à 6 horas ( ) De 6 à 8 horas ( ) Mais que 8 horas 
Termo de Consentimento Livre e Esclarecido

Você está sendo convidado a participar de uma pesquisa intitulada "Estudo do Comportamento Cooperativo por Meio do Dilema do Prisioneiro Iterado", a qual será acompanhada pelos seguintes pesquisadores: Thiago Camargo Corrêa - aluno de mestrado do programa de neurociências e comportamento do Instituto de Psicologia da universidade de São Paulo; Prof ${ }^{\mathrm{a}}$. Dra ${ }^{\mathrm{a}}$. Ivana Brito - orientadora e pesquisadora do programa de neurociências e comportamento do Instituto de Psicologia da universidade de São Paulo.

Esta pesquisa tem como objetivo avaliar a ação do neuro-hormônio ocitocina no comportamento em jogos. A ocitocina já está presente em nosso organismo, tanto em homens quanto em mulheres, e será administrado sob a forma de spray nasal, em baixas doses e sem implicações. Não trará dano ou consequências a sua saúde, nem será realizado nenhum procedimento invasivo. Outros estudos já foram desenvolvidos e nenhum prejuízo foi relatado ao utilizar ocitocina na via intranasal

Sua participação no jogo proposto será precedida de algumas avaliações de algumas características fisiológicas gerais com auxílio de questionários. Em seguida será administrada, por meio de spray nasal, uma solução que pode ou não conter ocitocina.

Caso no decorrer das atividades desista de participar, poderemos interromper as atividades sem qualquer constrangimento. Seus dados serão confidenciais e serão unicamente de uso do pesquisador Thiago Camargo Corrêa e orientadora para a elaboração da dissertação de mestrado e sua posterior publicação em forma de artigo.

$\mathrm{Eu}$, portador o RG tendo lido as informações acima, voluntariamente concordo em participar do referido projeto de pesquisa, estando ciente dos meus direitos e possibilidades de desistência sem qualquer ônus ou prejuízo. 
Escala de Humor

Abaixo está uma lista de palavras que descrevem sentimentos. Por favor, leia tudo atenciosamente. Em seguida assinale, em cada linha, o quadrado que melhor descreve COMO VOCÊ SE SENTE AGORA. Tenha certeza de sua resposta para cada questão, antes de assinalar.

Escala:

$0=$ nada $1=$ um pouco $2=$ moderadamente $3=$ bastante $4=$ extremamente

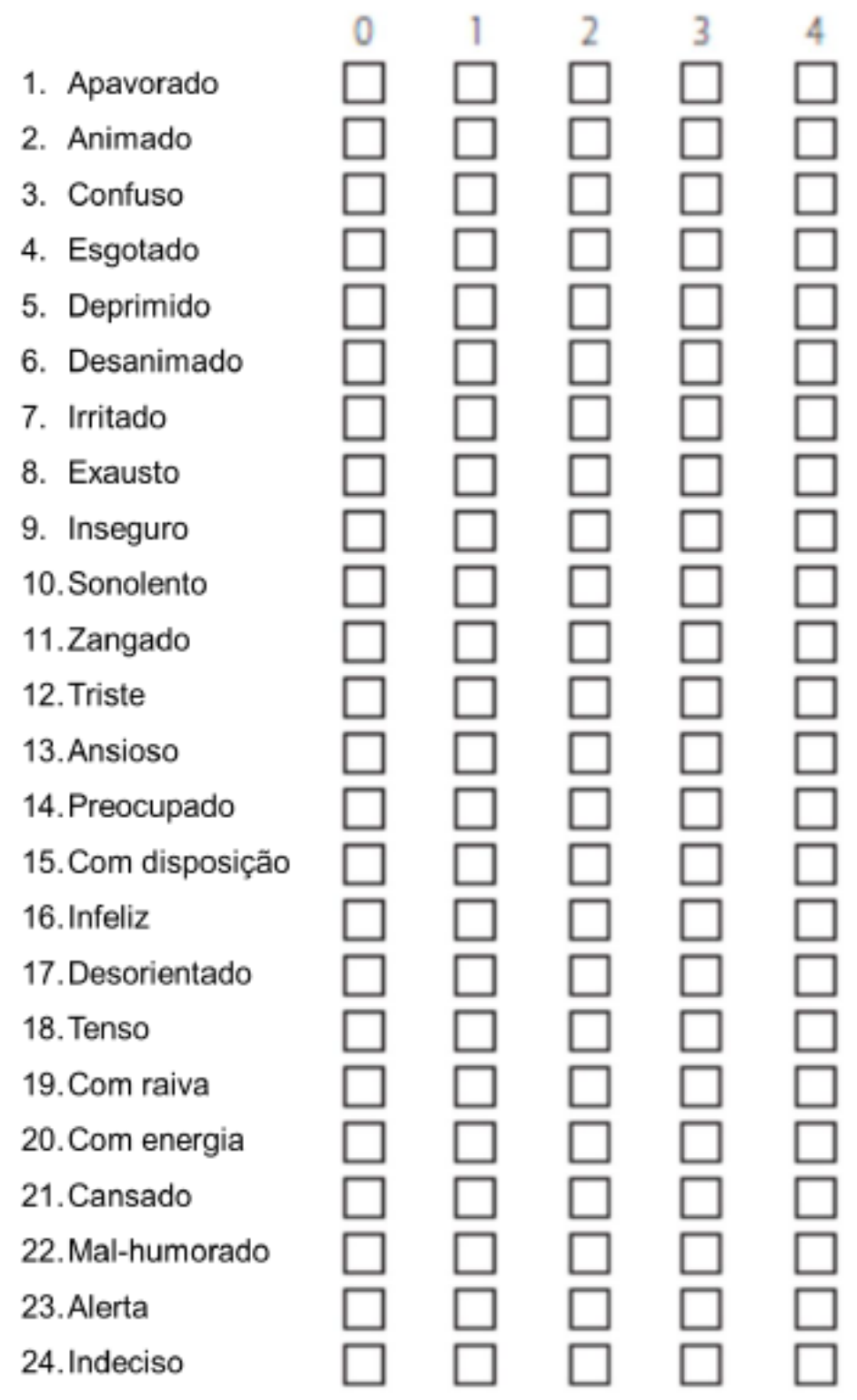


Anexo 4

Você tem 5 minutos para realizar esse teste. Nele é preciso marcar todas as figuras iguais ao gabarito fornecido (representado no retângulo abaixo). O instrutor marcará o fim dessa atividade.

Assinale o teste conforme a demonstração

$\rightarrow \quad ㅁ \square$

$\bigoplus$ cound

GUIA DO

CRIVO

$\bigoplus$

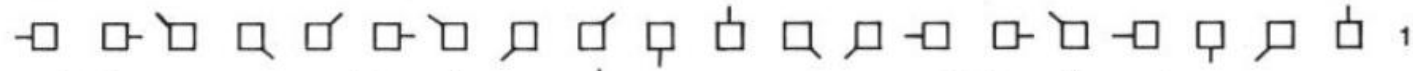

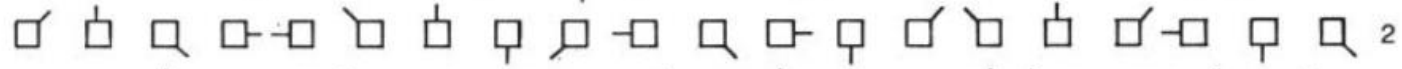

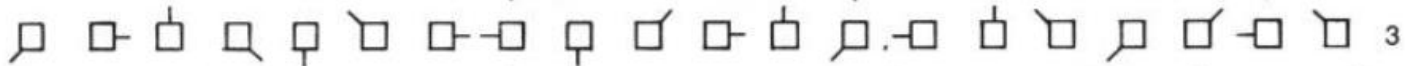

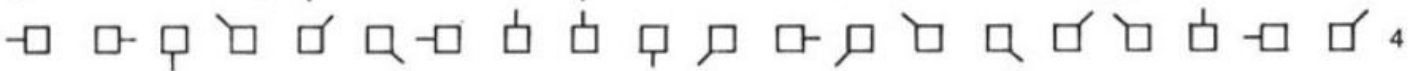

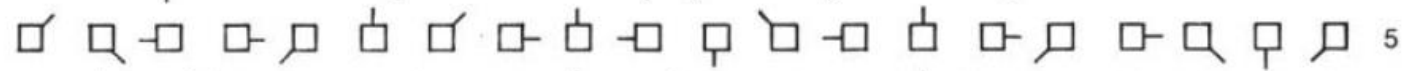

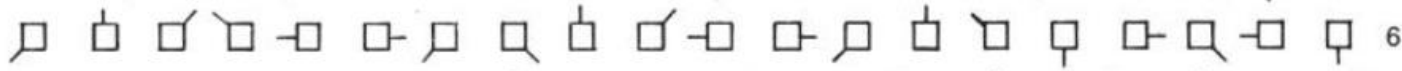

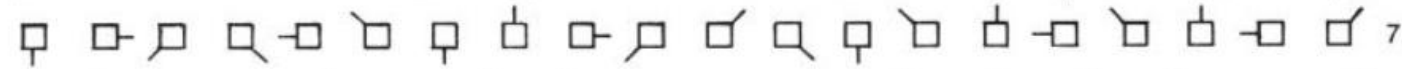

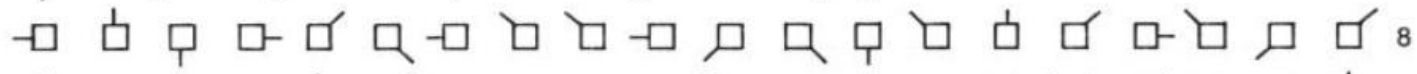

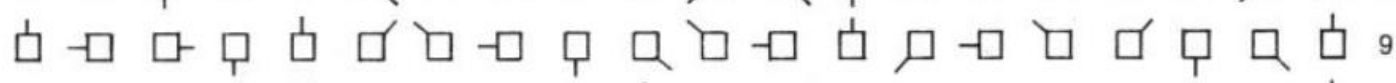

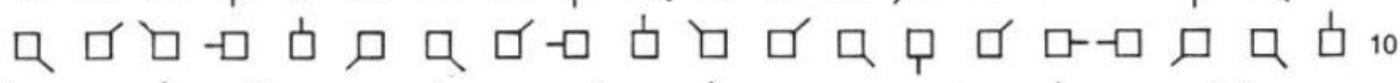

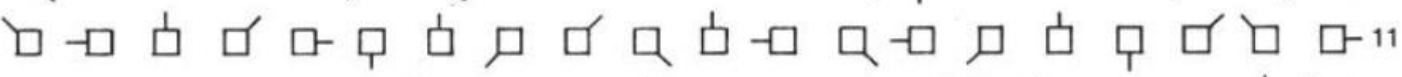

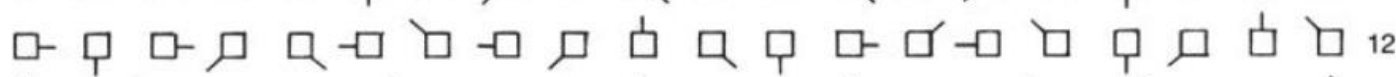

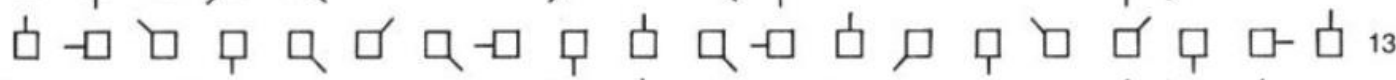

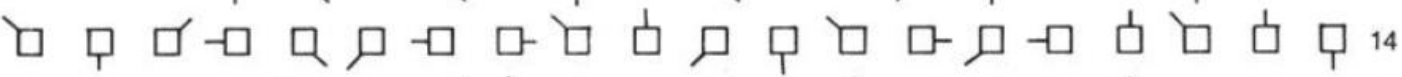

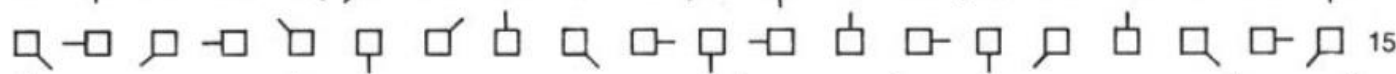

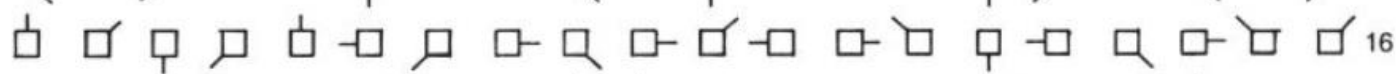

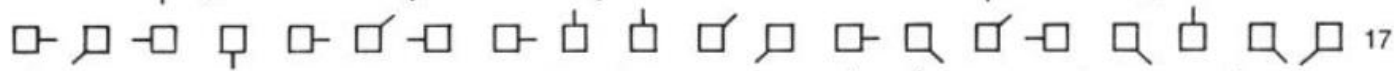

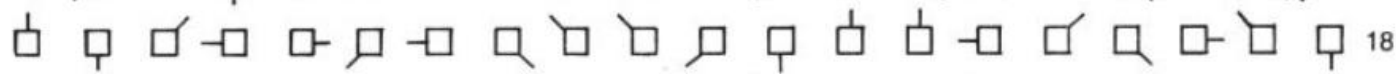
•只只

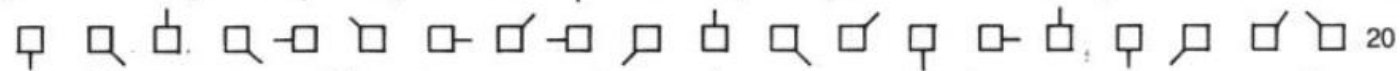

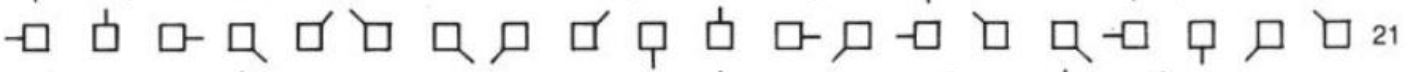

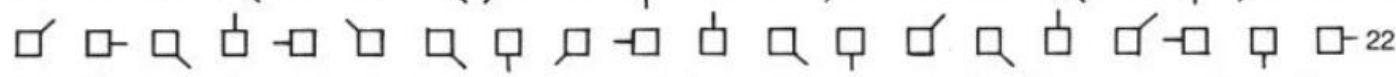
- 